ARTICLE

https://doi.org/10.1038/s41467-019-11586-y

\title{
Enhancing photoelectrochemical water splitting by combining work function tuning and heterojunction engineering
}

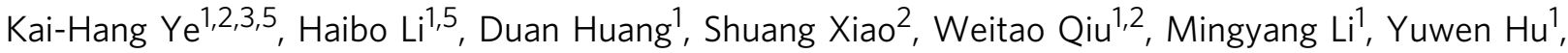 \\ Wenjie Mai (i) ${ }^{3}$, Hongbing Ji (i) ${ }^{1} \&$ Shihe Yang ${ }^{2,4}$
}

We herein demonstrate the unusual effectiveness of two strategies in combination to enhance photoelectrochemical water splitting. First, the work function adjustment via molybdenum (Mo) doping significantly reduces the interfacial energy loss and increases the open-circuit photovoltage of bismuth vanadate $\left(\mathrm{BiVO}_{4}\right)$ photoelectrochemical cells. Second, the creation and optimization of the heterojunction of boron $(B)$ doping carbon nitride $\left(\mathrm{C}_{3} \mathrm{~N}_{4}\right)$ and $\mathrm{Mo}$ doping $\mathrm{BiVO}_{4}$ to enforce directional charge transfer, accomplished by work function adjustment via $\mathrm{B}$ doping for $\mathrm{C}_{3} \mathrm{~N}_{4}$, substantially boost the charge separation of photogenerated electron-hole pairs at the $\mathrm{B}-\mathrm{C}_{3} \mathrm{~N}_{4}$ and $\mathrm{Mo}-\mathrm{BiVO}_{4}$ interface. The synergy between the above efforts have significantly reduced the onset potential, and enhanced charge separation and optical properties of the $\mathrm{BiVO}_{4}$-based photoanode, culminating in achieving a record applied bias photon-to-current efficiency of $2.67 \%$ at $0.54 \mathrm{~V}$ vs. the reversible hydrogen electrode. This work sheds light on designing and fabricating the semiconductor structures for the next-generation photoelectrodes.

\footnotetext{
${ }^{1}$ Fine Chemical Industry Research Institute, School of Chemistry, Sun Yat-sen University, 510275 Guangzhou, China. ${ }^{2}$ Guangdong Key Lab of Nano-Micro Material Research, School of Chemical Biology and Biotechnology, Shenzhen Graduate School, Peking University, Xili University Town, 518055 Shenzhen, China. ${ }^{3}$ Siyuan Laboratory, Guangzhou Key Laboratory of Vacuum Coating Technologies and New Energy Materials, Guangdong Provincial Engineering Technology Research Center of Vacuum Coating Technologies and New Energy Materials, Department of Physics, Jinan University, 510632 Guangzhou, China. ${ }^{4}$ Department of Chemistry, The Hong Kong University of Science and Technology, 999077 Clear Water Bay, Kowloon, Hong Kong, China. ${ }^{5}$ These authors contributed equally: Kai-Hang Ye, Haibo Li. Correspondence and requests for materials should be addressed to H.J. (email: jihb@mail.sysu.edu.cn) or to S.Y. (email: chsyang@pku.edu.cn)
} 
P hotoelectrochemical cell (PEC) for water splitting is a key technology of the future for hydrogen production ${ }^{1-3}$. Despite the widespread attention that has been received, this technology still has many hurdles to overcome and uncharted territories to explore. Ultimately, the photon to hydrogen conversion efficiency has yet to be increased to such a level that commercial applications could become viable ${ }^{4}$.

In the PEC water splitting process, photons are first absorbed by the photoelectrode producing electrons and holes, which are then separated and participated in the hydrogen evolution reaction (HER) on cathode and the oxygen evolution reaction (OER) on anode, possibly with the assistance of a bias voltage ${ }^{1}$. Therefore, one way to enhance the PEC efficiency is to increase the quantum efficiency of photons in a PEC system by improving the efficiencies of light harvesting, charge separation and surface charge transfer ${ }^{3-10}$. Another strategy to enhance the PEC efficiency is to minimize the overpotential by reducing the voltage loss related to charge recombination, sluggish surface kinetics, etc.

$\mathrm{BiVO}_{4}$ has received great attention in recent years because it is a promising sustainability-inspired photoanode material for PEC with a suitable band gap for visible light absorption ${ }^{11}$ and favorable conduction band edge position (0.1-0.2 V vs. NHE) for $\mathrm{H}_{2}$ evolution ${ }^{7}$. However, the PEC efficiency at low bias voltages of $\mathrm{BiVO}_{4}$ photoanode still has much room for improvement ${ }^{11-13}$. In particular, due to the presence of numerous trap states and surface defects as well as the associated surface Fermi-level pinning effect, the $\mathrm{BiVO}_{4}$ films variously prepared so far are still plagued by the quite low open-circuit photo-voltage when used as photoanodes $^{11,14,15}$. To address this issue, doped photoanodes, such as $\mathrm{W}-\mathrm{BiVO}_{4}, \mathrm{Mo}-\mathrm{BiVO}_{4}$, have been fabricated aiming to enhance charge transport and to reduce the charge recombination ${ }^{11,12,16,17}$. Meanwhile, $\mathrm{W}-\mathrm{BiVO}_{4} / \mathrm{BiVO}_{4}, \mathrm{Co}_{2} \mathrm{O}_{3}$ / $\mathrm{BiVO}_{4}$, and $\mathrm{BiOI} / \mathrm{BiVO}_{4}$ photoanodes have been developed in the form of so-called homojunctions and heterojunctions to enhance the charge separation in PEC systems $s^{6,13,18}$. Other problems of the $\mathrm{BiVO}_{4}$-based photoanode include the still low coverage of the solar spectrum which it is able to harvest as well as the low charge separation efficiency. To address these problems, carbon quantum dots $/ \mathrm{BiVO}_{4}$ and nitrogen doped $\mathrm{BiVO}_{4}$ photoanodes have been reported showing broadened light absorption range, enhanced light harvesting efficiency, and boosted interfacial charge transfer for PEC water splitting ${ }^{9,18}$. As for improving the utilization efficiency of surface charge for oxygen evolution, the combined catalyst/photoelectrode systems, such as $\mathrm{FeOOH} /$ $\mathrm{BiVO}_{4}, \mathrm{NiFeO}_{\mathrm{x}} / \mathrm{BiVO}_{4}, \mathrm{Co}-\mathrm{Pi} / \mathrm{BiVO}_{4}$, and $\mathrm{NiOOH} / \mathrm{FeOOH} /$ $\mathrm{BiVO}_{4}$, have been commonly used ${ }^{7,19-21}$.

Recent efforts have improved the photocurrent density of $\mathrm{BiVO}_{4}$ based photoanodes for water splitting to nearly $90 \%$ of its theoretical value at $1.23 \mathrm{~V}$ vs. $\mathrm{RHE}^{22,23}$. However, the photon to hydrogen conversion efficiency is still far from its theoretical value mainly due to the stagnant carrier transport. Especially when a PEC cell works at low bias, the carrier transport is more susceptible to blockage by any potential barriers in the energy landscape along the carrier passage. Specifically, poor performance at low bias of $\mathrm{BiVO}_{4}$ based photoanodes led to poor applied bias photon-to-current efficiencies (ABPEs) as reported in some PEC water splitting systems, such as $\mathrm{Bi}-\mathrm{NiFeO}_{\mathrm{x}} / \mathrm{BiVO}_{4}$ $(2.25 \%)^{20}, \mathrm{NiOOH} / \mathrm{FeOOH} / \mathrm{BiVO}_{4}(1.75 \%)^{7}, \mathrm{NiO} / \mathrm{CoO}_{\mathrm{x}} / \mathrm{BiVO}_{4}$ $(1.5 \%)^{11}, \mathrm{NiOOH} / \mathrm{FeOOH} / \mathrm{N}-\mathrm{BiVO}_{4}(2.2 \%)^{9}$. Previously, nanostructures and cocatalysts have been used to promote photocurrents and to minimize onset potentials, respectively ${ }^{7,19-21}$.

Meanwhile, because $\mathrm{C}_{3} \mathrm{~N}_{4}$ has a favorable conduction band edge position relative to that of $\mathrm{BiVO}_{4}$, a heterojunction between the two could increase the charge separation. Prompted by this expectation, the conjugation of $\mathrm{C}_{3} \mathrm{~N}_{4}$ with $\mathrm{BiVO}_{4}$ has received great attention in recent years ${ }^{24-28}$. However, before the $\mathrm{C}_{3} \mathrm{~N}_{4}$ /
$\mathrm{BiVO}_{4}$ junction could efficiently drive the PEC water splitting, new strategies must be developed to elaborate the band structure at the junction to optimize charge separation by minimizing interfacial kinetic barriers and energy losses.

In this work, we endeavored to explore such ways to further improve the PEC performance of the $\mathrm{BiVO}_{4}$ photoanode. First, we systematically studied the effect of Mo doping on the electron band structure of $\mathrm{BiVO}_{4}$, and discovered that a moderate $\mathrm{Mo}$ doping of $\mathrm{BiVO}_{4}$, a low end doping regime that has not been explored before, can increase the photo-voltage of $\mathrm{BiVO}_{4}$ photoanodes from $0.24 \mathrm{~V}$ to $\sim 1 \mathrm{~V}$ in $10 \mathrm{~s}$ irradiation. Second, to further improve the charge separation efficiency at low bias, we elaborated a cliff like junction between $\mathrm{B}-\mathrm{C}_{3} \mathrm{~N}_{4}$ and $\mathrm{Mo}-\mathrm{BiVO}_{4}$, for which the band structure of $\mathrm{C}_{3} \mathrm{~N}_{4}$ was judiciously tuned as well by $\mathrm{B}$ doping. With such an elaborated junction, interfacial charge transfer was remarkably enhanced. As the main thread running through this work, we make special efforts to advance our ability to modulate the work functions with a view to toning up the $\mathrm{NiFeO}_{\mathrm{x}} / \mathrm{B}-\mathrm{C}_{3} \mathrm{~N}_{4} / \mathrm{Mo}-\mathrm{BiVO}_{4}$ photoanodes for $\mathrm{PEC}$ water splitting. We have significantly increased the light harvesting efficiency (LHE) of the $\mathrm{B}-\mathrm{C}_{3} \mathrm{~N}_{4} / \mathrm{Mo}-\mathrm{BiVO}_{4}$ photoanode, achieving photocurrent densities of $4.7 \mathrm{~mA} \mathrm{~cm}^{-2}$ at $0.6 \mathrm{~V}$ vs. RHE $\left(\Phi_{\text {Sep }}=79 \%\right)$ and $6 \mathrm{~mA} \mathrm{~cm}^{-2}$ at $1.23 \mathrm{~V}$ vs. $\operatorname{RHE}\left(\Phi_{\mathrm{Sep}}=98 \%\right)$ in potassium phosphate buffer (PPB) solution with $0.5 \mathrm{M} \mathrm{Na}_{2} \mathrm{SO}_{3}$ hole scavenger ( $\mathrm{pH} 7$ ). When the $\mathrm{NiFeO}_{\mathrm{x}}$ was anchored on the B$\mathrm{C}_{3} \mathrm{~N}_{4} / \mathrm{Mo}-\mathrm{BiVO}_{4}$ photoanode as an OER catalyst layer forming the $\mathrm{NiFeO}_{\mathrm{x}} / \mathrm{B}-\mathrm{C}_{3} \mathrm{~N}_{4} / \mathrm{Mo}-\mathrm{BiVO}_{4}$ photoanode, we obtained photocurrent densities of $3.85 \mathrm{~mA} \mathrm{~cm}^{-2}$ at $0.54 \mathrm{~V}$ vs. RHE $(71 \%$ IPCE) and $5.93 \mathrm{~mA} \mathrm{~cm}^{-2}$ at $1.23 \mathrm{~V}$ vs. RHE (92\% IPCE) in PPB solution without any hole scavengers such as $\mathrm{Na}_{2} \mathrm{SO}_{3}(\mathrm{pH}$ 7). Significantly, the $\mathrm{NiFeO}_{\mathrm{x}} / \mathrm{B}-\mathrm{C}_{3} \mathrm{~N}_{4} / \mathrm{Mo}-\mathrm{BiVO}_{4}$ photoanode has achieved an ABPE up to $2.67 \%$ at $0.54 \mathrm{~V}$ vs. RHE, which is the highest reported to date and yet, with the lowest biased-voltage, for $\mathrm{BiVO}_{4}$-based PEC devices.

\section{Results}

Characterization of the $\mathrm{NiFeO}_{\mathrm{x}} / \mathrm{B}-\mathrm{C}_{3} \mathrm{~N}_{4} / \mathrm{Mo}-\mathrm{BiVO}_{4}$ photoanode. The XRD patterns collected from $\mathrm{BiVO}_{4}, \mathrm{Mo}-\mathrm{BiVO}_{4}, \mathrm{~B}-$ $\mathrm{C}_{3} \mathrm{~N}_{4} / \mathrm{Mo}-\mathrm{BiVO}_{4}, \mathrm{NiFeO}_{\mathrm{x}} / \mathrm{B}-\mathrm{C}_{3} \mathrm{~N}_{4} / \mathrm{Mo}-\mathrm{BiVO}_{4}$ prepared on the Fdoped $\mathrm{SnO}_{2}$ conducting glass (FTO), $\mathrm{C}_{3} \mathrm{~N}_{4}$ and $\mathrm{B}-\mathrm{C}_{3} \mathrm{~N}_{4}$ are shown in Supplementary Fig. 1. All of the diffraction peaks in the XRD patterns obtained can be well indexed to monoclinic $\mathrm{BiVO}_{4}$ (JCPDS PDF \#75-1866), $\mathrm{SnO}_{2}$ (JCPDS PDF \#41-1445) and graphite- $\mathrm{C}_{3} \mathrm{~N}_{4}$ (JCPDS PDF $\left.\# 50-1250\right)^{18,29,30}$. As shown in Fig. 1a, the champion photoanode consisted of nanoporous B- $\mathrm{C}_{3} \mathrm{~N}_{4} / \mathrm{Mo}-\mathrm{BiVO}_{4}$ heterojunctions in tandem with a $\mathrm{NiFeO}_{\mathrm{x}}$ oxygen evolution catalyst (OEC) layer, which were successfully grown on the FTO substrate. (Supplementary Fig. 2) As shown in Fig. 1b-g, signals of $\mathrm{Bi}, \mathrm{C}, \mathrm{O}$, and Fe elements are clearly observed in a row, suggesting that the newly-coated $\mathrm{B}-\mathrm{C}_{3} \mathrm{~N}_{4}$ has covered the nanoporous $\mathrm{Mo}_{-} \mathrm{BiVO}_{4}$, and $\mathrm{NiFeO}_{\mathrm{x}}$ layer has covered the $\mathrm{B}$ $\mathrm{C}_{3} \mathrm{~N}_{4} / \mathrm{Mo}-\mathrm{BiVO}_{4}$ as the OEC. Figures $1 \mathrm{~h}, \mathrm{i}$ is a typical TEM image and a high-resolution TEM (HRTEM) image of the $\mathrm{NiFeO}_{\mathrm{x}} / \mathrm{B}-$ $\mathrm{C}_{3} \mathrm{~N}_{4} / \mathrm{Mo}-\mathrm{BiVO}_{4}$ sample, respectively, revealing that the $\mathrm{B}-\mathrm{C}_{3} \mathrm{~N}_{4}$ and $\mathrm{Mo}-\mathrm{BiVO}_{4}$ are crystallized (Fig. 1j, k) while $\mathrm{NiFeO}_{\mathrm{x}}$ is noncrystallized (Fig. 11). The lattice fringes of $0.325 \mathrm{~nm}$ and $0.254 \mathrm{~nm}$ are ascribed to the (002) plane ${ }^{31}$ of $\mathrm{C}_{3} \mathrm{~N}_{4}$ and the (020) plane $^{32}$ of $\mathrm{BiVO}_{4}$, respectively.

Work function tuning. The first strategy we used to optimize the PEC performance of $\mathrm{BiVO}_{4}$-based photoanodes, more precisely, to lower the onset potential, was to systematically adjust the work function by Mo doping below $1 \%$, which is a previously uncharted doping regime (the atomic ratio is shown in Supplementary Table 1). Figure $2 \mathrm{a}$ compares the linear sweep 

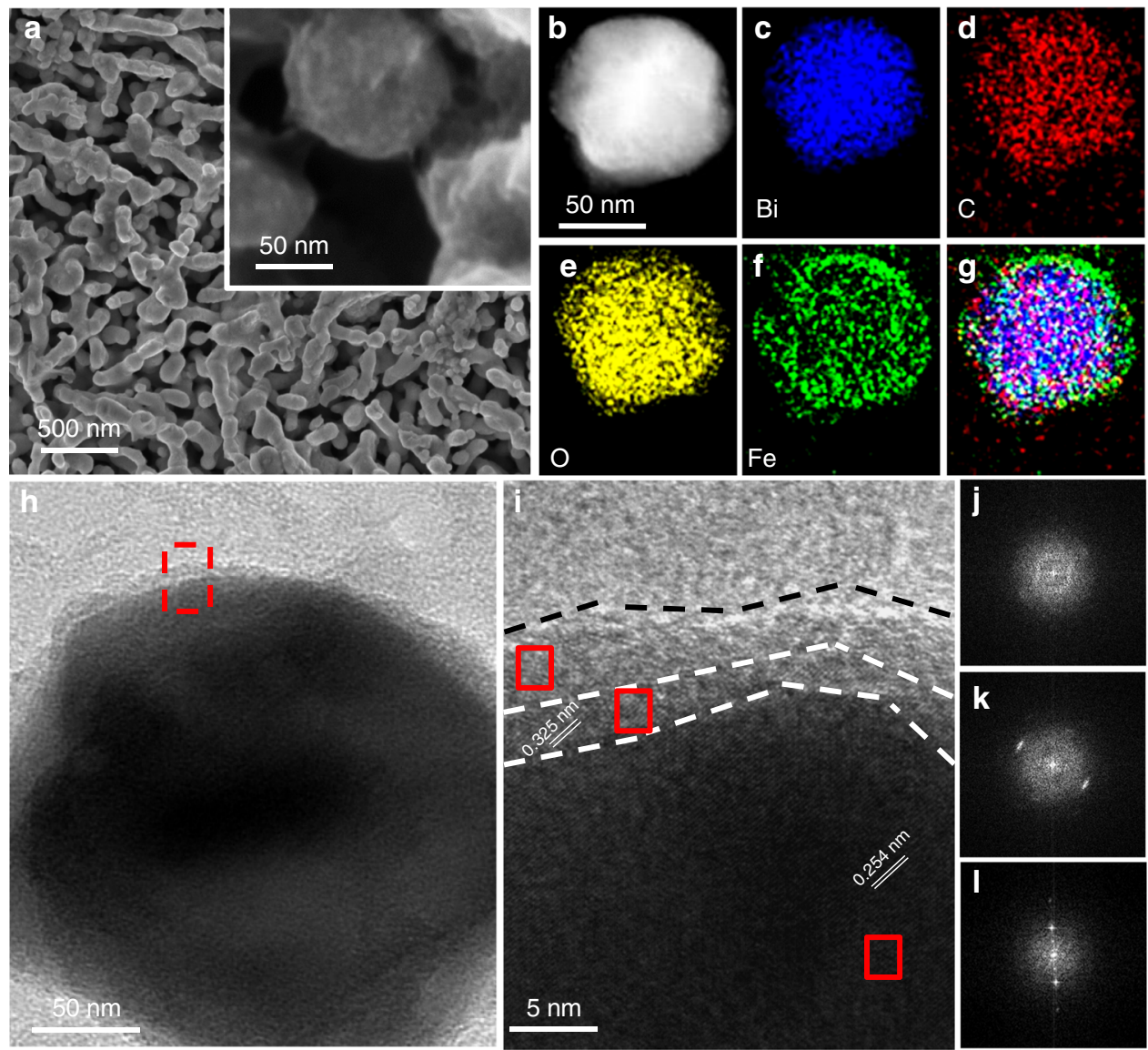

Fig. 1 Electron microscopic characterization of the $\mathrm{NiFeO} \times / \mathrm{B}-\mathrm{C}_{3} \mathrm{~N}_{4} / \mathrm{Mo}-\mathrm{BiVO}_{4}$ photoanodes. a Top-view (inset is the magnified image) SEM images of the $\mathrm{NiFeO}_{x} / \mathrm{B}-\mathrm{C}_{3} \mathrm{~N}_{4} / \mathrm{Mo}^{-\mathrm{BiVO}_{4}}$ photoanode. b HADDF-STEM image of the $\mathrm{NiFeO}_{x} / \mathrm{B}_{-} \mathrm{C}_{3} \mathrm{~N}_{4} / \mathrm{Mo}-\mathrm{BiVO}_{4}$ photoanode and c-f the corresponding STEM-EDS elemental mapping images for $\mathrm{Bi}, \mathrm{C}, \mathrm{O}$, and $\mathrm{Fe}$, respectively. $\mathbf{g}$ Overlay of the elemental mapping images of Fe, $\mathrm{C}$, and $\mathrm{Bi}$. $\mathbf{h}$ TEM, $\mathbf{i} \mathrm{HRTEM}$ image of the

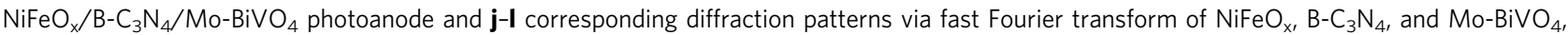
respectively

voltammograms (LSV) curves of $\mathrm{BiVO}_{4}$ (black line), $0.05 \% \mathrm{Mo}$ doped $\mathrm{BiVO}_{4}$ (blue line) and $0.1 \%$ Mo doped $\mathrm{BiVO}_{4}$ (red line) $0.5 \%$ Mo doped $\mathrm{BiVO}_{4}$ (purple line) at a scan rate of $25 \mathrm{mV} \mathrm{s}^{-1}$ in $0.5 \mathrm{M} \mathrm{Na}_{2} \mathrm{SO}_{3}$ aqueous solution as a hole scavenger with PPB $(\mathrm{pH} 7)$ under AM $1.5 \mathrm{G}$ one-sun illumination. The pure $\mathrm{BiVO}_{4}$ photoanode achieved photocurrent density of $3.2( \pm 0.3) \mathrm{mA} \mathrm{cm}^{-2}$ at $0.6 \mathrm{~V}$ vs. RHE and $4.7( \pm 0.3) \mathrm{mA} \mathrm{cm}^{-2}$ at $1.23 \mathrm{~V}$ vs. RHE, in agreement with the previous report ${ }^{7}$. With a slight doping, the photocurrent density of $0.1 \% \mathrm{Mo}^{-\mathrm{BiVO}_{4}}$ increased to $3.4( \pm 0.2)$ $\mathrm{mA} \mathrm{cm}{ }^{-2}$ at $0.6 \mathrm{~V}$ vs. RHE and $4.98( \pm 0.2) \mathrm{mA} \mathrm{cm}^{-2}$ at $1.23 \mathrm{~V}$ vs. RHE. From our extensive measurements, the photocurrent densities assuming $100 \%$ absorbed photon-to-current efficiency $\left(J_{\text {abs }}\right)$ of the $\mathrm{BiVO}_{4}$-based and the $\mathrm{Mo}-\mathrm{BiVO}_{4}$-based photoanodes were consistently $\sim 4.7 \mathrm{~mA} \mathrm{~cm}^{-2}$ and $\sim 5.01 \mathrm{~mA} \mathrm{~cm}^{-2}$, respectively (Supplementary Fig. 3). The increase in $J_{\text {abs }}$ could be ascribed to the enhanced LHE, carrier concentration (Supplementary Fig. 27) and mobility (Supplementary Fig. 28) resulting from the Mo doping ${ }^{33-37}$. More interestingly, the onset potential of Mo doped $\mathrm{BiVO}_{4}(0.05,0.1$, and $0.5 \%)$ photoanodes became significantly more negative than that of pure $\mathrm{BiVO}_{4}$ photoanode, and the rapid photocurrent increase region against bias for the $0.05 \%$ and $0.1 \%$ Mo doped $\mathrm{BiVO}_{4}$ is also more negative than that of the $\mathrm{BiVO}_{4}$ photoanode. However, the rapid photocurrent increase region against bias for the $0.5 \%$ Mo doped $\mathrm{BiVO}_{4}$ is more positive than that of $\mathrm{BiVO}_{4}$. This phenomenon is caused by the changed opencircuit photo-voltage (OCP) of $\mathrm{BiVO}_{4}$ due to the work function adjustment by the Mo doping.
Supplementary Fig. 5 shows OCP changes of the Mo doped $\mathrm{BiVO}_{4}(0.05,0.1$, and $0.5 \%)$ relative to the pure $\mathrm{BiVO}_{4}$ photoanode due to the truncation of Fermi-level pinning and surface trap states of $\mathrm{BiVO}_{4}$. OCP is essentially the difference between open-circuit voltage in dark $\left(\mathrm{OCV}_{\text {dark }}\right)$ and light $\left(\mathrm{OCV}_{\text {light }}\right)$. The work function is tuned in such a way that the Fermi level $\left(\mathrm{E}_{\mathrm{f}}\right)$ is far from CBM when light is off resulting in a small OCV $_{\text {dark, }}$, but when light is on (AM 1.5 G), the quasi-Fermilevel $\left(\mathrm{E}_{\mathrm{fn}}\right)$ becomes as close as possible to $\mathrm{CBM}$ giving rise to a large $\mathrm{OCV}_{\text {light }}$. Consequently, a large OCP $\left(\mathrm{V}_{\mathrm{ph}}\right)$ can be obtained. Shown in Supplementary Fig. 5 are the OCP timing profiles of the Mo doped $\mathrm{BiVO}_{4}(0.05,0.1$, and $0.5 \%)$ and the pure $\mathrm{BiVO}_{4}$ photoanodes in PPB solution with the $\mathrm{Na}_{2} \mathrm{SO}_{3}$ hole scavenger $(\mathrm{pH} 7)$ over a testing interval of $30 \mathrm{~s}$ (Supplementary Fig. 5a) and $2000 \mathrm{~s}$ (Supplementary Fig. 5b). The most important observation is that the $0.1 \% \mathrm{Mo}^{-} \mathrm{BiVO}_{4}$ photoanode achieved the highest OCP $(\sim 1 \mathrm{~V}$ in the first irradiation on/off cycle, and $\sim 0.55 \mathrm{~V}$ in the cycles after testing for $1600 \mathrm{~s}$ ). These OCP values are much higher than those of pure- $\mathrm{BiVO}_{4}(\sim 0.35 \mathrm{~V}$ and $\sim 0.15 \mathrm{~V}), 0.05 \%$ Mo$\mathrm{BiVO}_{4}(\sim 0.8 \mathrm{~V}$ and $\sim 0.4 \mathrm{~V})$, and $0.5 \% \mathrm{Mo}^{-}-\mathrm{BiVO}_{4}$ photoanode $(\sim 0.23 \mathrm{~V}$ and $\sim 0.16 \mathrm{~V})$ when tested under otherwise the same conditions. A higher OCP value means a more favorable driving force for water oxidation since it determines the difference between the hole quasi-Fermi-level of the semiconductor heterojunction and the redox potential of the electrolyte.

The above presented OCP result can be captured by the picture illustrated in Fig. 2b. For the pure $\mathrm{BiVO}_{4}$, the Fermi-level position 
a
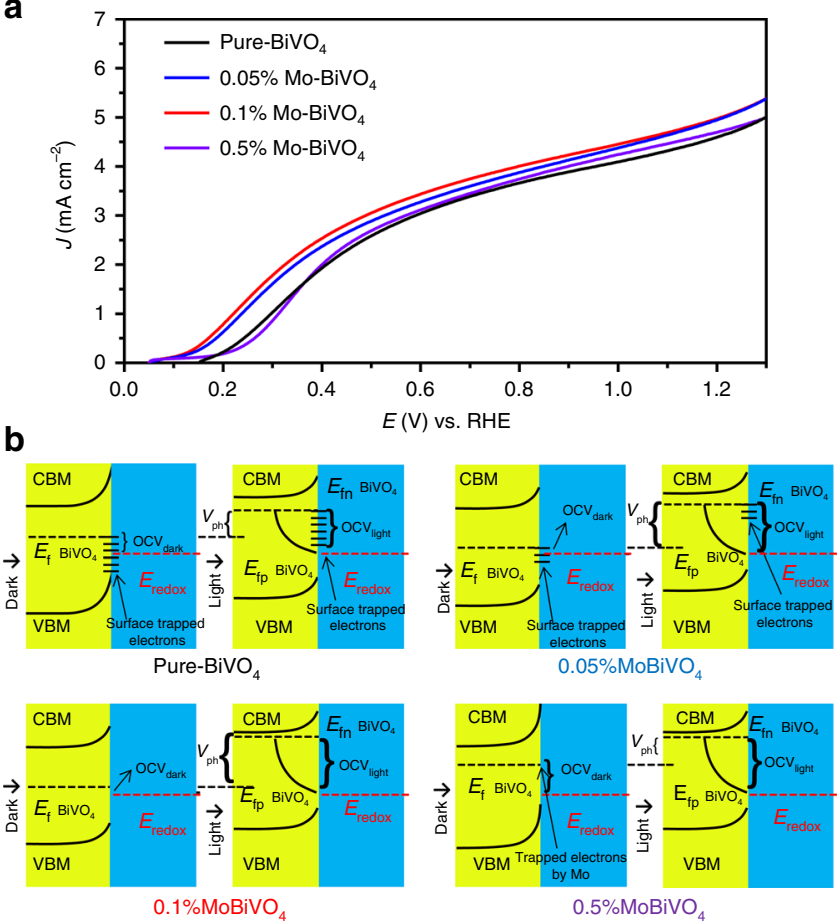

Fig. 2 Photoelectrochemical and photo-voltage characterization of the $\mathrm{BiVO}_{4}$-based photoanodes. a LSV curves of pure- $-\mathrm{BiVO}_{4}, 0.05 \% \mathrm{Mo}-\mathrm{BiVO}_{4}$,

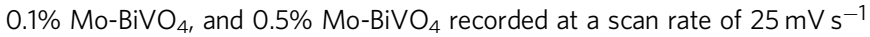
under AM $1.5 \mathrm{G}$ one-sun irradiation in PPB solution with $0.5 \mathrm{M} \mathrm{Na}_{2} \mathrm{SO}_{3}$ as a hole scavenger $(\mathrm{pH} 7)$. $\mathbf{b}$ Band structures and band bending schematics of pure- $\mathrm{BiVO}_{4}, 0.05 \% \mathrm{Mo}^{-} \mathrm{BiVO}_{4}, 0.1 \% \mathrm{Mo}^{-\mathrm{BiVO}_{4}}$, and 0.5\% Mo-BiVO constructed from the XPS, UPS and photoelectrochemical measurement data

of ideal $\mathrm{BiVO}_{4}$ is close the valence band edge of $\mathrm{BiVO}_{4}{ }^{9}$, but the lattice defects formed during synthesis and surface state trapped electrons $\left(\mathrm{V}^{4+}\right)$ of pure $\mathrm{BiVO}_{4}$ move the $\mathrm{E}_{\mathrm{f}}$ of pure $\mathrm{BiVO}_{4}$

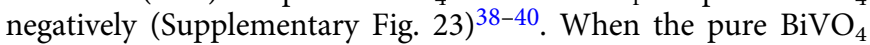
photoanode was immersed in the solution, the $\mathrm{E}_{\mathrm{f}}$ of pure $\mathrm{BiVO}_{4}$ became more negative than the redox potential due to Fermi-level pinning by surface trapped electrons, making the $\mathrm{OCV}_{\text {dark }}$ of $\mathrm{BiVO}_{4}$ relatively high ${ }^{11}$. Meanwhile, under AM $1.5 \mathrm{G}$ illumination, the Fermi-level pinning effect prevented the $\mathrm{E}_{\mathrm{fn}}$ moving very close to the conduction band minimum (CBM) of $\mathrm{BiVO}_{4}{ }^{11,38}$, leading to a moderate $\mathrm{OCV}_{\text {light }}$ and thus a low OCP $\left(\mathrm{V}_{\mathrm{ph}}\right)$ of pure $\mathrm{BiVO}_{4}$ very low. Importantly, the Mo doping in $\mathrm{BiVO}_{4}$ could reduce the surface trap states and at the same time introduced new states, thus moderating the Fermi-level pinning effect (Supplementary Fig. 4) ${ }^{41}$. Due to the reduced Fermi-level pinning effect by Mo doping, for the $0.05 \%$ and $0.1 \% \mathrm{Mo}-\mathrm{BiVO}_{4}$ photoanodes, the $\mathrm{E}_{\mathrm{f}}$ and $\mathrm{E}_{\mathrm{fn}}$ became more positive and negative than $\mathrm{E}_{\mathrm{f}}$ of the pure $\mathrm{BiVO}_{4}$ photoanode, respectively, thereby enhancing the OCPs. However, for the $0.5 \% \mathrm{Mo}^{-} \mathrm{BiVO}_{4}$, new states were introduced due to the excess Mo doping, and the $\mathrm{E}_{\mathrm{f}}$ became much closer to $\mathrm{CBM}$, leading to high $\mathrm{OCV}_{\text {dark }}$ (Supplementary Fig. 6) and thus a low OCP. As such, the OCP of $0.1 \% \mathrm{Mo}^{-} \mathrm{BiVO}_{4}$ is the best of all the samples we studied, in agreement with the corresponding PEC performance as will be presented below. As can be seen from Fig. 2a, the photocurrent density of $0.1 \% \mathrm{Mo}-\mathrm{BiVO}_{4}$ reached $5.0( \pm 0.2) \mathrm{mA} \mathrm{cm}^{-2}$ at $1.23 \mathrm{~V}$ vs. RHE in solution with hole scavenger, which represents $\sim 73 \%$ the theoretical water oxidation photocurrent density $\left(J_{\max }\right)$ of $\mathrm{BiVO}_{4}\left(6.8 \mathrm{~mA} \mathrm{~cm}^{-2}\right)$. Thus the moderate Mo doping of $\mathrm{BiVO}_{4}$ in the low end doping regime can increase the photo-voltage carrier concentration and mobility of the $\mathrm{BiVO}_{4}$ photoanodes, and improve their onset potential and photocurrent density.

Heterojunction engineering. We now turn to our second strategy to optimize the PEC performance of $\mathrm{BiVO}_{4}$-based photoanodes by further increasing the utilization of $J_{\max }$. To accomplish it, we started with the basic $\mathrm{C}_{3} \mathrm{~N}_{4} / \mathrm{BiVO}_{4}$ junction, and then work up for optimization by B-doping $\mathrm{C}_{3} \mathrm{~N}_{4}$ and the Mo-doping $\mathrm{BiVO}_{4}$. Both LHE and charge separation have been enhanced, leading to the increase of $J_{\mathrm{abs}}$ and $\Phi_{\text {Sep }}$ of the photoanode. Supplementary Fig. 7 shows the UV-vis absorption spectra from the diffuse reflectance measurements and photographs of $\mathrm{B}-\mathrm{C}_{3} \mathrm{~N}_{4}$ and $\mathrm{C}_{3} \mathrm{~N}_{4}$. From visual inspection, the yellow color of $\mathrm{B}-\mathrm{C}_{3} \mathrm{~N}_{4}$ is clearly deeper than $\mathrm{C}_{3} \mathrm{~N}_{4}$, and correspondingly, the absorption of $\mathrm{B}-\mathrm{C}_{3} \mathrm{~N}_{4}$ is also stronger than $\mathrm{C}_{3} \mathrm{~N}_{4}$. From the plots in Supplementary Fig. 8a of $(a h v)^{2}$ vs. the photon energy (hv), the band-gap energy of $\mathrm{C}_{3} \mathrm{~N}_{4}$ and $\mathrm{B}-\mathrm{C}_{3} \mathrm{~N}_{4}$ are $2.53 \mathrm{eV}$ and $2.41 \mathrm{eV}$, respectively. Supplementary Fig. $8 \mathrm{~b}$ is the LHE of B$\mathrm{C}_{3} \mathrm{~N}_{4} / \mathrm{Mo}-\mathrm{BiVO}_{4}$, which exhibits stronger absorption in the range between $300 \mathrm{~nm}$ and $500 \mathrm{~nm}$ than Mo-BiVO . Supplementary Fig. $8 \mathrm{c}$ shows the spectra of the solar irradiance of AM $1.5 \mathrm{G}$ (ASTM G173-03) and those weighted by the LHE spectra of B$\mathrm{C}_{3} \mathrm{~N}_{4} / \mathrm{Mo}-\mathrm{BiVO}_{4}$, which shows the $J_{\text {abs }}$ of $\mathrm{B}-\mathrm{C}_{3} \mathrm{~N}_{4} / \mathrm{Mo}-\mathrm{BiVO}_{4}$ achieved $\sim 6.0 \mathrm{~mA} \mathrm{~cm}^{-2}$. Figure $3 \mathrm{a}$ compares the LSV curves of $0.1 \% \mathrm{Mo}^{-\mathrm{BiVO}_{4}}$ (black line), $\mathrm{C}_{3} \mathrm{~N}_{4} / \mathrm{Mo}-\mathrm{BiVO}_{4}$ (cyan line) and $\mathrm{B}$ $\mathrm{C}_{3} \mathrm{~N}_{4} / \mathrm{Mo}-\mathrm{BiVO}_{4}$ (purple line) at a scan rate of $25 \mathrm{mV} \mathrm{s}^{-1}$ using $0.5 \mathrm{M} \mathrm{Na}_{2} \mathrm{SO}_{3}$ as a hole scavenger in a PPB buffered aqueous solution ( $\mathrm{pH} 7)$ under AM $1.5 \mathrm{G}$ irradiation. The photocurrent density of $\mathrm{B}-\mathrm{C}_{3} \mathrm{~N}_{4} / \mathrm{Mo}-\mathrm{BiVO}_{4}$ reached $\sim 6 \mathrm{~mA}( \pm 0.2) \mathrm{cm}^{-2}$ at $1.23 \mathrm{~V}$ vs. RHE, and this is higher than that of $0.1 \% \mathrm{Mo}-\mathrm{BiVO}_{4}$ $\left(5 \mathrm{~mA} \mathrm{~cm}^{-2}\right)$, at least partly due to the increase in LHE and $J_{\text {abs }}$ after the conjugation with $\mathrm{B}-\mathrm{C}_{3} \mathrm{~N}_{4}$. At $0.6 \mathrm{~V}$ vs. RHE, the photocurrent density of $\mathrm{B}-\mathrm{C}_{3} \mathrm{~N}_{4} / \mathrm{Mo}-\mathrm{BiVO}_{4}$ was $4.7 \mathrm{~mA} \mathrm{~cm}{ }^{-2}$, which is much higher than that of $0.1 \% \mathrm{Mo}^{-B_{i V O}}\left(3.4 \mathrm{~mA} \mathrm{~cm}{ }^{-2}\right)$. However, the photocurrent of $\mathrm{C}_{3} \mathrm{~N}_{4} / \mathrm{Mo}-\mathrm{BiVO}_{4}$ only achieved 2.9 and $4.2 \mathrm{~mA} \mathrm{~cm}^{-2}$ at 0.6 and $1.23 \mathrm{~V}$ vs. RHE, which are lower than that of $\mathrm{Mo}^{-} \mathrm{BiVO}_{4}\left(3.4\right.$ and $\left.5 \mathrm{~mA} \mathrm{~cm}{ }^{-2}\right)$, although increased LHE and $J_{\text {abs }}$ by compositing $\mathrm{C}_{3} \mathrm{~N}_{4}$ and $\mathrm{B}-\mathrm{C}_{3} \mathrm{~N}_{4}$. The results of $\Phi_{\text {Sep }}$ of Mo- $\mathrm{BiVO}_{4}$ (black line), $\mathrm{C}_{3} \mathrm{~N}_{4} / \mathrm{Mo}-\mathrm{BiVO}_{4}$ (cyan line) and $\mathrm{B}-\mathrm{C}_{3} \mathrm{~N}_{4} /$ Mo- $\mathrm{BiVO}_{4}$ (purple line) clearly shows that $\mathrm{B}-\mathrm{C}_{3} \mathrm{~N}_{4}$ decoration can great increase the $\Phi_{\text {Sep }}$ of $\mathrm{Mo}-\mathrm{BiVO}_{4}$, while pure $\mathrm{C}_{3} \mathrm{~N}_{4}$ decoration will reduce the $\Phi_{\text {Sep }}$ of $\mathrm{Mo}^{-\mathrm{BiVO}_{4}}$ (Fig. 3b). The $\Phi_{\text {Sep }}$ of $\mathrm{B}-\mathrm{C}_{3} \mathrm{~N}_{4} /$

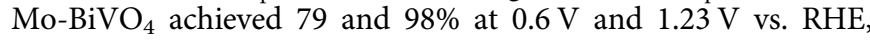
respectively. The $\Phi_{\text {Sep }}$ of $\mathrm{B}-\mathrm{C}_{3} \mathrm{~N}_{4} / \mathrm{Mo}-\mathrm{BiVO}_{4}$ at $0.6 \mathrm{~V}$ vs. RHE is higher than that of $\mathrm{Mo}-\mathrm{BiVO}_{4}(69 \%)$, and at $1.23 \mathrm{~V}$ vs. RHE, the $\Phi_{\text {Sep }}$ of $\mathrm{Mo}-\mathrm{BiVO}_{4}$ andB- $\mathrm{C}_{3} \mathrm{~N}_{4} / \mathrm{Mo}-\mathrm{BiVO}_{4}$ are achieved near $100 \%$ cause the charge separation of $\mathrm{Mo}-\mathrm{BiVO}_{4}$ and $\mathrm{B}-\mathrm{C}_{3} \mathrm{~N}_{4} / \mathrm{Mo}-$ $\mathrm{BiVO}_{4}$ have reached their limits at higher bias voltage. However, the $\Phi_{\text {Sep }}$ of $\mathrm{C}_{3} \mathrm{~N}_{4} / \mathrm{Mo}-\mathrm{BiVO}_{4}$ only achieved 60 and $80 \%$ at $0.6 \mathrm{~V}$ and $1.23 \mathrm{~V}$ vs. RHE, which are even lower than that of Mo$\mathrm{BiVO}_{4}$. This result shows that when $\mathrm{C}_{3} \mathrm{~N}_{4}$ is compositing the Mo$\mathrm{BiVO}_{4}$, it has no effect on the separation of the photo-generated charges. These results mean that although the thermodynamic potential of pure $\mathrm{C}_{3} \mathrm{~N}_{4}$ and $\mathrm{Mo}-\mathrm{BiVO}_{4}$ are match, the heterojunction of pure $\mathrm{C}_{3} \mathrm{~N}_{4}$ and $\mathrm{Mo}-\mathrm{BiVO}_{4}$ became a compound center of photo-generated charge.

As shown in Fig. $3 c$, d, when the Mo- $\mathrm{BiVO}_{4}$ and pure $\mathrm{C}_{3} \mathrm{~N}_{4}$ are in contact, the O1s and V2p positive shift $0.34 \mathrm{eV}$ and N1s negative shifts $0.96 \mathrm{eV}$. Supplementary Fig. 9 shows the CBM, VBM and Fermi level of $\mathrm{BiVO}_{4}, \mathrm{Mo}-\mathrm{BiVO}_{4}, \mathrm{C}_{3} \mathrm{~N}_{4}$ and $\mathrm{B}-\mathrm{C}_{3} \mathrm{~N}_{4}$ by UPS and XPS VB spectra data (Supplementary Figs. 10, 11, 12, and 13). The Fermi level of $\mathrm{BiVO}_{4}$ and $\mathrm{Mo}-\mathrm{BiVO}_{4}$ are in the middle of their band gap $\left(\mathrm{BiVO}_{4}: 1.21 \mathrm{eV}\right.$ and $\mathrm{Mo}-\mathrm{BiVO}_{4}$ : $1.16 \mathrm{eV}$ ) and the Fermi level of $\mathrm{B}-\mathrm{C}_{3} \mathrm{~N}_{4}$ is close to its VBM, and the Fermi level of pure $\mathrm{C}_{3} \mathrm{~N}_{4}$ is close to its CBM. The DFT data 

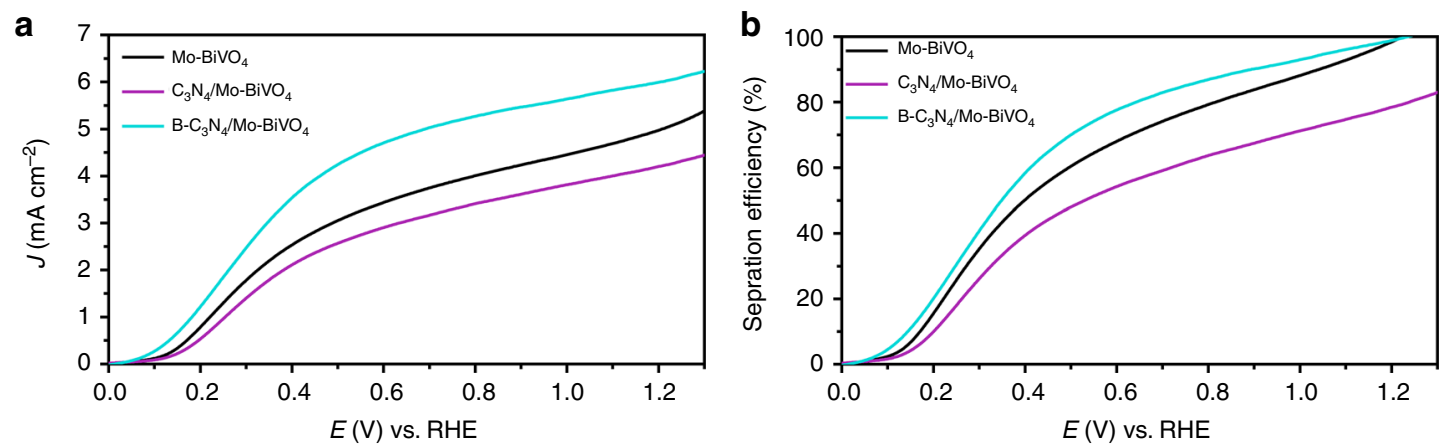

C

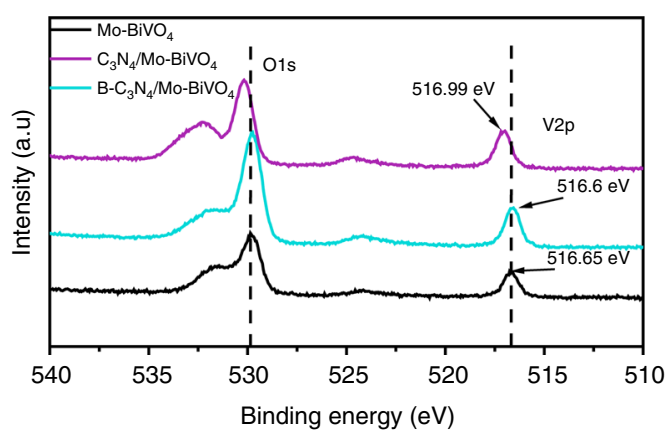

d

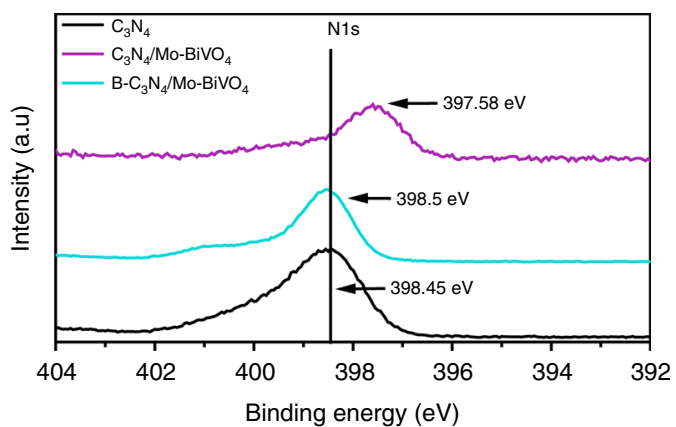

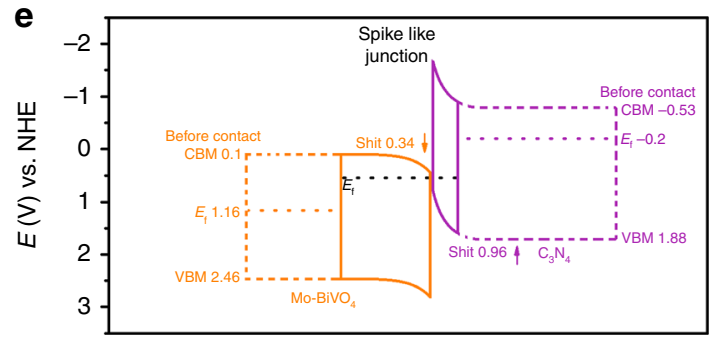

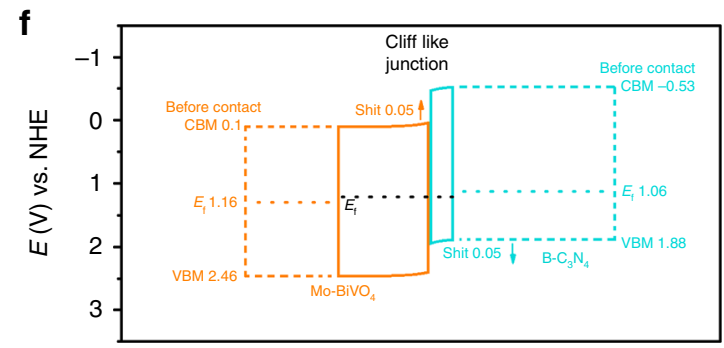

Fig. 3 Photoelectrochemical performances and charge transfer processes. a LSV curves of $\mathrm{C}_{3} \mathrm{~N}_{4} / \mathrm{Mo}-\mathrm{BiVO} \mathrm{O}_{4}, 0.1 \% \mathrm{Mo}-\mathrm{BiVO}_{4}$ and $\mathrm{B}-\mathrm{C}_{3} \mathrm{~N}_{4} / \mathrm{Mo}_{0}-\mathrm{BiVO} \mathrm{O}_{4}$ measured at a scan rate of $25 \mathrm{mV} \mathrm{s}^{-1}$ under AM $1.5 \mathrm{G}$ irradiation in PPB solution with $\mathrm{Na}_{2} \mathrm{SO}_{3}$ as a hole scavenger ( $\mathrm{pH}$ 7). b Separation efficiency ( $\Phi_{\text {Sep }}$ ) of $\mathrm{C}_{3} \mathrm{~N}_{4} / \mathrm{Mo}-\mathrm{BiVO}_{4}, 0.1 \% \mathrm{Mo}^{-B i V O}{ }_{4}$ and $\mathrm{B}-\mathrm{C}_{3} \mathrm{~N}_{4} / \mathrm{Mo}^{-B i V O} \mathrm{O}_{4}$. XPS core-level shifts of $\mathbf{c} \vee 2 \mathrm{p}, \mathrm{O} 1 \mathrm{~s}$ and $\mathbf{d} \mathrm{N} 1 \mathrm{~s}$. Schematic diagrams of the band structures of e $\mathrm{C}_{3} \mathrm{~N}_{4} / \mathrm{Mo}-\mathrm{BiVO}_{4}, \mathbf{f}-\mathrm{C}_{3} \mathrm{~N}_{4} / \mathrm{Mo}-\mathrm{BiVO}_{4}$

confirms that the Fermi energy level of $\mathrm{Mo}-\mathrm{BiVO}_{4}$ and $\mathrm{B}-\mathrm{C}_{3} \mathrm{~N}_{4}$ changed after Mo and $\mathrm{B}$ element doping (Supplementary Fig. 14). In detail, when $\mathrm{Mo}-\mathrm{BiVO}_{4}$ and $\mathrm{C}_{3} \mathrm{~N}_{4}$ come into contact to form a heterojunction, the bands on the two sides bend oppositely into the spike-like structure (Fig. 3e), and thus the electrons from the $\mathrm{C}_{3} \mathrm{~N}_{4}$ side can hardly transfer to the $\mathrm{Mo}-\mathrm{BiVO}_{4}$ side. The holes inside $\mathrm{Mo}-\mathrm{BiVO}_{4}$ will hardly transfer to $\mathrm{C}_{3} \mathrm{~N}_{4}$, as the existence of energy barrier at the interface. Therefore, the contact interface of pure $\mathrm{C}_{3} \mathrm{~N}_{4}$ and $\mathrm{Mo}-\mathrm{BiVO}_{4}$ will reduce the separation of photogenerated charges. On the other hand, due to the $\mathrm{B}$ element doping, the Fermi level of $\mathrm{B}-\mathrm{C}_{3} \mathrm{~N}_{4}$ is getting closer to the VBM (Supplementary Fig. 9b). As shown in Fig. 3d, when the $\mathrm{Mo}-\mathrm{BiVO}_{4}$ and $\mathrm{B}-\mathrm{C}_{3} \mathrm{~N}_{4}$ are in contact, a cliff like junction is formed with the correct charge transfer direction, which will increase the separation of photo-generated charges. Supplementary Fig. 15 displays the Raman spectra of $\mathrm{Mo}-\mathrm{BiVO}_{4}, \mathrm{C}_{3} \mathrm{~N}_{4}, \mathrm{~B}-\mathrm{C}_{3} \mathrm{~N}_{4}, \mathrm{C}_{3} \mathrm{~N}_{4} / \mathrm{Mo}-\mathrm{BiVO}_{4}$ and $\mathrm{B}-\mathrm{C}_{3} \mathrm{~N}_{4} / \mathrm{Mo}-\mathrm{BiVO}_{4}$. The Raman peaks at $702 \mathrm{~cm}^{-1}$ and $746 \mathrm{~cm}^{-1}$ are attributed to the $\mathrm{C}-\mathrm{N}$ vibration of $\mathrm{B}-\mathrm{C}_{3} \mathrm{~N}_{4}$ (Blue line). The peak at $816 \mathrm{~cm}^{-1}$ are attributed to the $\mathrm{V}-\mathrm{O}$ vibration, while the peaks at $362 \mathrm{~cm}^{-1}$ and $323 \mathrm{~cm}^{-1}$ can be attributed to the $\mathrm{VO}_{4}{ }^{3-}$ vibration of the $\mathrm{Mo}-\mathrm{BiVO}_{4}$. The Raman peaks of $\mathrm{B}-\mathrm{C}_{3} \mathrm{~N}_{4}$ $\left(702 \mathrm{~cm}^{-1}, 746 \mathrm{~cm}^{-1}\right)$ and $\mathrm{Mo}^{-B_{i V O}}\left(362 \mathrm{~cm}^{-1}, 323 \mathrm{~cm}^{-1}\right)$ shifted to $545 \mathrm{~cm}^{-1}, 620 \mathrm{~cm}^{-1}$, and $340 \mathrm{~cm}^{-1}, 314 \mathrm{~cm}^{-1}$ in $\mathrm{B}-\mathrm{C}_{3} \mathrm{~N}_{4} / \mathrm{Mo}-\mathrm{BiVO}_{4}$ sample, indicating the formation of chemical bonds between $\mathrm{B}-\mathrm{C}_{3} \mathrm{~N}_{4}$ and $\mathrm{Mo}-\mathrm{BiVO}_{4}$. In other words, the $\mathrm{B}-\mathrm{C}_{3} \mathrm{~N}_{4}$ is chemically linked to $\mathrm{Mo}-\mathrm{BiVO}_{4}$.

PEC water splitting performance. In order to use the $\mathrm{B}-\mathrm{C}_{3} \mathrm{~N}_{4} /$ $\mathrm{Mo}^{-\mathrm{BiVO}_{4}}$ photoanode for PEC water splitting in solution without hole scavenger, the $\mathrm{NiFeO}_{\mathrm{x}}$ layer was used as an OEC material, which was deposited on the photo-active area of $\mathrm{B}-\mathrm{C}_{3} \mathrm{~N}_{4} / \mathrm{Mo}$ $\mathrm{BiVO}_{4}$ photoanode surface by photoelectrodeposition method. Supplementary Figs. 16 and 17 show the XPS data of Ni, N, B, C, Bi, $\mathrm{Mo}, \mathrm{O}$, and Fe. For B-doped $\mathrm{C}_{3} \mathrm{~N}_{4}$, as can be seen from Supplementary Figs. 16c, the peak of $B$ is located at around $191.9 \mathrm{eV}$, fairly close to the binding energy of $\mathrm{B}$ in the $-\mathrm{C}-\mathrm{N}-\mathrm{B}-$ and $-\mathrm{N}-\mathrm{B}-(\mathrm{N})_{2}-$ groups $(192.1 \mathrm{eV})$ of the $\mathrm{B}-\mathrm{C}_{3} \mathrm{~N}_{4}$ materials reported in the literature ${ }^{42}$. The oxidation state of $\mathrm{B}$ is consistent with the results of $\mathrm{B}$ doped $\mathrm{C}_{3} \mathrm{~N}_{4}$ in the reported literature ${ }^{27}$. As shown in Fig. $4 \mathrm{a}$ and Supplementary Fig. 21, the PEC water splitting capability of $\mathrm{NiFeO}_{\mathrm{x}} / \mathrm{B}-\mathrm{C}_{3} \mathrm{~N}_{4} / \mathrm{Mo}-\mathrm{BiVO}_{4}$ photoanode (orange solid line) achieves $4.18 \mathrm{~mA} \mathrm{~cm}^{-2}$ and $5.93( \pm 0.3) \mathrm{mA} \mathrm{cm}^{-2}$ at $0.6 \mathrm{~V}$ vs. RHE and $1.23 \mathrm{~V}$ vs. RHE in PPB solution ( $\mathrm{pH} 7$ ), which are much higher than that of $\mathrm{Mo}^{-} \mathrm{BiVO}_{4}$ photoanode and $\mathrm{B}-\mathrm{C}_{3} \mathrm{~N}_{4} / \mathrm{Mo}-\mathrm{BiVO}_{4}$, Meanwhile, the photocurrent density of $\mathrm{NiFeO}_{\mathrm{x}} / \mathrm{B}-\mathrm{C}_{3} \mathrm{~N}_{4} / \mathrm{Mo}-$ $\mathrm{BiVO}_{4}$ photoanode at $0.6 \mathrm{~V}$ vs. $\mathrm{RHE}$ and $1.23 \mathrm{~V}$ vs. RHE are much close to that of $\mathrm{NiFeO}_{\mathrm{x}} / \mathrm{B}-\mathrm{C}_{3} \mathrm{~N} / \mathrm{Mo}-\mathrm{BiVO}_{4}$ photoanode (orange dotted line) in PPB solution with $\mathrm{Na}_{2} \mathrm{SO}_{3}$ hole scavenger ( $\mathrm{pH} 7$, 

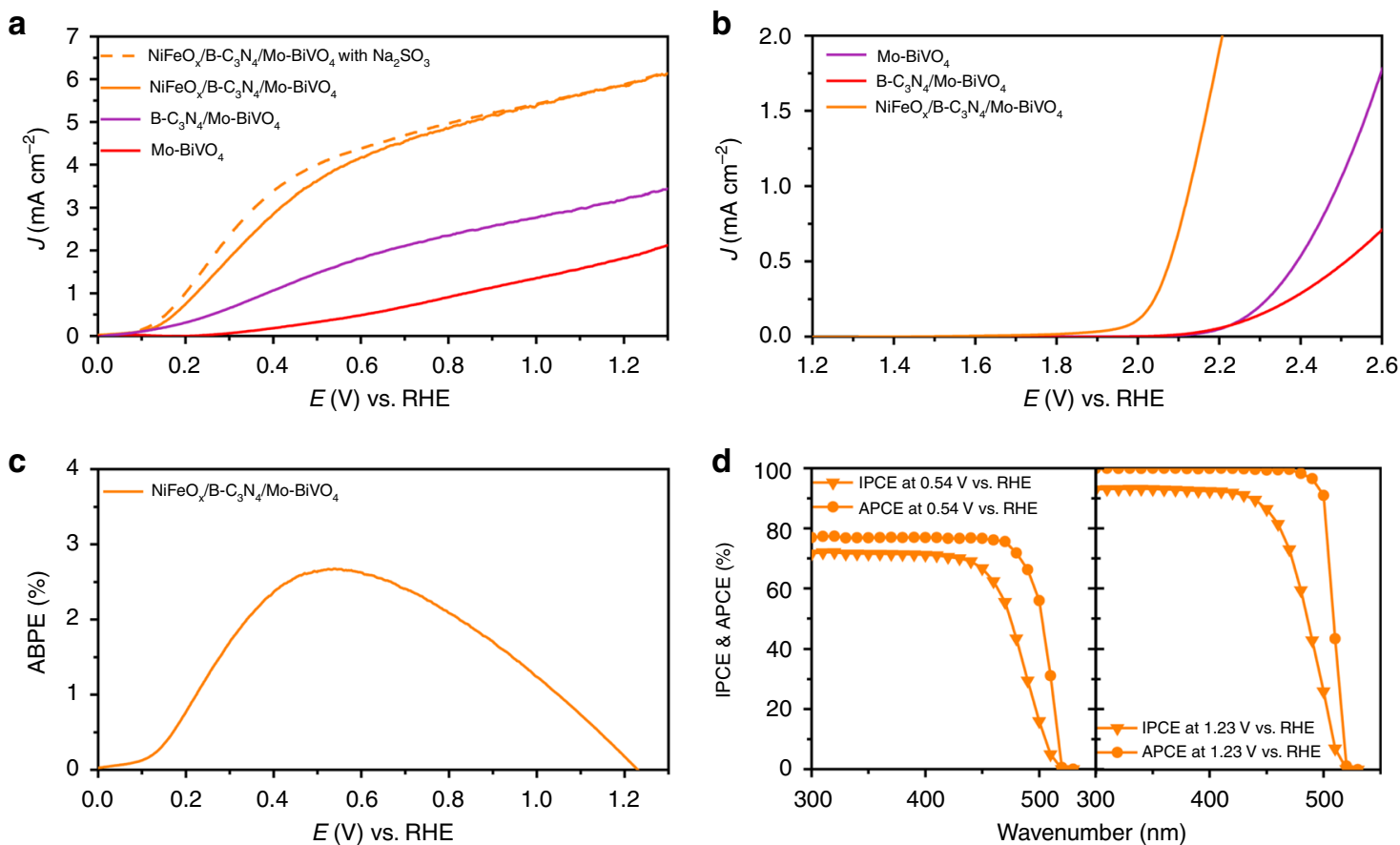

Fig. 4 Photoelectrochemical performances. LSV curves of the $\mathrm{Mo}-\mathrm{BiVO}_{4}, \mathrm{~B}-\mathrm{C}_{3} \mathrm{~N}_{4} / \mathrm{Mo}-\mathrm{BiVO}_{4}$ and $\mathrm{NiFeO} / \mathrm{B}-\mathrm{C}_{3} \mathrm{~N}_{4} / \mathrm{Mo}^{-B i V O_{4}}$ recorded at a scan rate of $25 \mathrm{mV} \mathrm{s}^{-1}$ in PPB solution without $\mathrm{Na}_{2} \mathrm{SO}_{3}$ as a hole scavenger $(\mathrm{pH} 7)$ a under $\mathrm{AM} 1.5 \mathrm{G}$ irradiation and $\mathbf{b}$ in dark. $\mathbf{c} \mathrm{ABPE}$ of NiFeO$\times \mathrm{B}-\mathrm{C}_{3} \mathrm{~N}_{4} / \mathrm{Mo}^{-\mathrm{BiVO}} \mathrm{O}_{4}$.

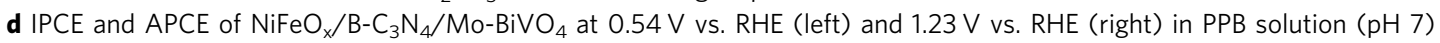

$4.37( \pm 0.3) \mathrm{mA} \mathrm{cm}^{-2}$ and $\left.5.96( \pm 0.3) \mathrm{mA} \mathrm{cm}^{-2}\right)$. Supplementary Fig. 18 shows that the $\mathrm{B}-\mathrm{C}_{3} \mathrm{~N}_{4}$ can not only increase the photocurrent density in the low biased-voltage range (0.1 0.8 V vs. RHE) by increasing the separation efficiency of photoanode, but also increase the photocurrent density in the high biased-voltage range $\left(0.8 \sim 1.3 \mathrm{~V}\right.$ vs. RHE). The IPCEs of $\mathrm{NiFeO}_{\mathrm{x}} / \mathrm{B}-\mathrm{C}_{3} \mathrm{~N}_{4} / \mathrm{Mo}-\mathrm{BiVO}_{4}$, $\mathrm{NiFeO}_{\mathrm{x}} / \mathrm{Mo}^{-\mathrm{BiVO}_{4},} \mathrm{NiFeO}_{\mathrm{x}} / \mathrm{BiVO}_{4}, \mathrm{~B}-\mathrm{C}_{3} \mathrm{~N}_{4} / \mathrm{Mo}-\mathrm{BiVO}_{4}, \mathrm{Mo}-$ $\mathrm{BiVO}_{4}$, and $\mathrm{BiVO}_{4}$ at $0.54 \mathrm{~V}$ vs. RHE in $\mathrm{PPB}$ solution ( $\mathrm{pH} 7$ ), which shows that the $\mathrm{B}-\mathrm{C}_{3} \mathrm{~N}_{4}$ can increase the charge separation efficiency and light absorption of photoanode. On the other hand, the $\mathrm{NiFeO}_{\mathrm{x}}$ cannot increase light absorption of photoanode, and it only plays the role of a co-catalyst (OEC) here (Supplementary Fig. 19). In Fig. $4 b$, due to the high oxygen evolution reaction capacity of $\mathrm{NiFeO}_{\mathrm{x}}$ OEC, the dark LSV of $\mathrm{NiFeO}_{\mathrm{x}} / \mathrm{B}-\mathrm{C}_{3} \mathrm{~N} / \mathrm{Mo}-$ $\mathrm{BiVO}_{4}$ photoanode shows a remarkable cathodic shift $(\sim 340 \mathrm{mV})$ of onset potential compared to $\mathrm{B}-\mathrm{C}_{3} \mathrm{~N}_{4} / \mathrm{Mo}-\mathrm{BiVO}_{4}$ photoanode and Mo- $\mathrm{BiVO}_{4}$ photoanode. However, the LSV curves of the $\mathrm{B}-\mathrm{C}_{3} \mathrm{~N}_{4} /$ Mo- $-\mathrm{BiVO}_{4}$ and $\mathrm{NiFeO}_{\mathrm{x}} / \mathrm{B}-\mathrm{C}_{3} \mathrm{~N}_{4} / \mathrm{Mo}-\mathrm{BiVO}_{4}$ recorded at a scan rate of $25 \mathrm{mV} \mathrm{s}^{-1}$ in $\mathrm{PPB}$ solution with $\mathrm{Na}_{2} \mathrm{SO}_{3}$ as a hole scavenger ( $\mathrm{pH}$ 7 ), which shows that the photocurrent density of samples measured in solution with $\mathrm{Na}_{2} \mathrm{SO}_{3}$ will decline after the $\mathrm{NiFeO}_{\mathrm{x}}$ layer deposition (Supplementary Fig. 20). Figure 4c shows the half-cell applied bias photo-to-current efficiency (ABPE) of the $\mathrm{NiFeO}_{\mathrm{x}} / \mathrm{B}$ $\mathrm{C}_{3} \mathrm{~N}_{4} / \mathrm{Mo}-\mathrm{BiVO}_{4}$ photoanode. The ABPE is calculated to be $2.67 \%$ at $0.54 \mathrm{~V}$ vs. $\mathrm{RHE}$, which is the highest recorded for $\mathrm{BiVO}_{4}$-based photoanodes (Fig. 6c). Evidently, the highest efficiency has been achieved for the $\mathrm{NiFeO}_{\mathrm{x}} / \mathrm{B}-\mathrm{C}_{3} \mathrm{~N}_{4} / \mathrm{Mo}-\mathrm{BiVO}_{4}$ photoanode at the lowest potential ( $0.54 \mathrm{~V}$ vs. RHE) among the previously reported values, which shows the highest performance of PEC water splitting for $\mathrm{BiVO}_{4}$-based photoanodes. Shown in Supplementary Figs. 25 and 26 are the LSV curves and ABPE measurement results in the two electrodes configuration $\left(\mathrm{NiFeO} / \mathrm{B}-\mathrm{C}_{3} \mathrm{~N}_{4} / \mathrm{Mo}-\mathrm{BiVO}_{4}\right.$ photoanode and $\mathrm{Pt}$ cathode) in $\mathrm{PPB}$ solution ( $\mathrm{pH} 7$ ). It can be seen that the ABPE of whole PEC system (without reference electrode) achieved $2.1 \%$ at $0.62 \mathrm{~V}$ vs. Pt. Figure $4 \mathrm{~d}$ shows the incident- photon-to-current conversion efficiency (IPCE) and the absorbed photon-to-current efficiency (APCE) spectra of $\mathrm{NiFeO}_{\mathrm{x}} / \mathrm{B}-\mathrm{C}_{3} \mathrm{~N}_{4} /$

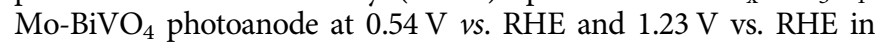
$\mathrm{PPB}$ solution ( $\mathrm{pH} 7$ ). The maximum IPCE value of $\mathrm{NiFeO}_{\mathrm{x}} / \mathrm{B}$ $\mathrm{C}_{3} \mathrm{~N}_{4} / \mathrm{Mo}-\mathrm{BiVO}_{4}$ photoanode reaches $\sim 71$ and $92 \%$ at $0.54 \mathrm{~V}$ vs. $\mathrm{RHE}$ and $1.23 \mathrm{~V}$ vs. RHE. The $\mathrm{APCE}$ of $\mathrm{NiFeO}_{\mathrm{x}} / \mathrm{B}-\mathrm{C}_{3} \mathrm{~N}_{4} / \mathrm{Mo}-$ $\mathrm{BiVO}_{4}$ photoanode reaches $\sim 100 \%$ at $1.23 \mathrm{~V}$ vs. RHE, establishing the $\mathrm{NiFeO}_{\mathrm{x}} / \mathrm{B}-\mathrm{C}_{3} \mathrm{~N}_{4} / \mathrm{Mo}-\mathrm{BiVO}_{4}$ photoanode used all the light it could absorb for PEC water splitting at $1.23 \mathrm{~V}$ vs. RHE. Therefore, these results clearly show that the $\mathrm{NiFeO}_{\mathrm{x}}$ OEC can greatly improve the $\mathrm{PEC}$ capacity of $\mathrm{B}-\mathrm{C}_{3} \mathrm{~N}_{4} / \mathrm{Mo}-\mathrm{BiVO}_{4}$ photoanode in the absence of any hole scavenger.

As shown in Fig. 5 and Supplementary Video 1, the $\mathrm{NiFeO}_{\mathrm{x}} / \mathrm{B}$ $\mathrm{C}_{3} \mathrm{~N} / \mathrm{Mo}-\mathrm{BiVO}_{4}$ photoanode exhibits excellent operational stability for half-cell PEC water splitting in PPB solution $(\mathrm{pH} 7)$ at $0.54 \mathrm{~V}$ vs. RHE under AM $1.5 \mathrm{G}$ irradiation. Figure $5 \mathrm{a}$ shows the photograph of the $\mathrm{NiFeO}_{\mathrm{x}} / \mathrm{B}-\mathrm{C}_{3} \mathrm{~N} / \mathrm{Mo}-\mathrm{BiVO}_{4}$ photoanode half-cell PEC water splitting system, and Fig. 5b-d show the photographs of the photoanode, the $\mathrm{Pt}$ cathode and the $\mathrm{Ag} / \mathrm{AgCl}$ reference electrode separately. The chronoamperometry curve of the $\mathrm{NiFeO}_{\mathrm{x}} / \mathrm{B}-\mathrm{C}_{3} \mathrm{~N}_{4} / \mathrm{Mo}-\mathrm{BiVO}_{4}$ photoanode was collected at $0.54 \mathrm{~V}$ vs. RHE in $10 \mathrm{~h}$. The photocurrent density of the $\mathrm{NiFeO}_{\mathrm{x}} / \mathrm{B}-\mathrm{C}_{3} \mathrm{~N}_{4} /$ $\mathrm{Mo}^{-\mathrm{BiVO}_{4}}$ photoanode was initially $3.85 \mathrm{~mA} \mathrm{~cm}^{-2}$ and decreased by only $10 \%$ after $10 \mathrm{~h}$ of operation, demonstrating the good stability of the $\mathrm{NiFeO}_{\mathrm{x}} / \mathrm{B}-\mathrm{C}_{3} \mathrm{~N}_{4} / \mathrm{Mo}-\mathrm{BiVO}_{4}$ photoanode during the long time irradiation in $\mathrm{PPB}$ solution (Fig. 5e). And the photocurrent densities of the $\mathrm{NiFeO}_{\mathrm{x}} / \mathrm{Mo}-\mathrm{BiVO}_{4}$ and $\mathrm{NiFeO}_{\mathrm{x}} / \mathrm{B}$ $\mathrm{C}_{3} \mathrm{~N}_{4} / \mathrm{Mo}-\mathrm{BiVO}_{4}$ photoanodes decayed by 5 and $8 \%$ (Supplementary Fig. 24), respectively, very close to the stability testing result of the $\mathrm{NiFeO}_{\mathrm{x}} / \mathrm{B}-\mathrm{C}_{3} \mathrm{~N}_{4} / \mathrm{Mo}-\mathrm{BiVO}_{4}$ photoanode at $0.54 \mathrm{~V}$ vs. RHE. These results confirm that the $\mathrm{NiFeO}_{\mathrm{x}}$ is a stable co-catalyst for the $\mathrm{BiVO}_{4}$-based photoanodes, essentially consistent with the recent reports. The generation rates of $\mathrm{H}_{2}$ and $\mathrm{O}_{2}$ by our half-cell system are measured to be $77.5 \mu \mathrm{M} / \mathrm{h}$ and $336 \mu \mathrm{m} 33.6 \mu \mathrm{M} / \mathrm{h}$, respectively, with Faradic efficiency of $98 \%$ (Fig. 5f). 

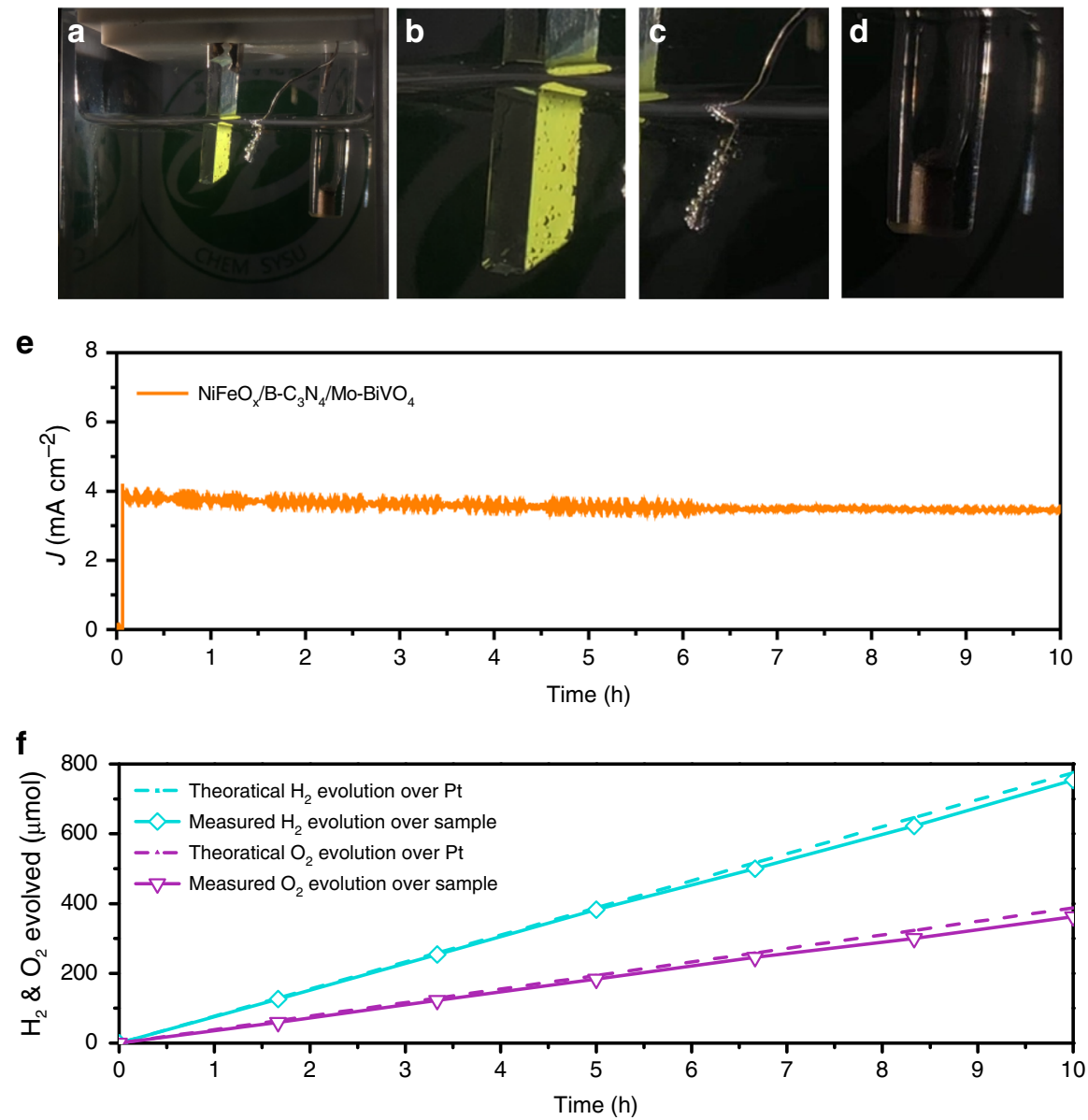

Fig. 5 Photoelectrochemical water splitting performances. Photographs of the $\mathrm{NiFeO} / \mathrm{B}-\mathrm{C}_{3} \mathrm{~N}_{4} / \mathrm{Mo}-\mathrm{BiVO}_{4}$ photoanode in the PEC water splitting system (a),

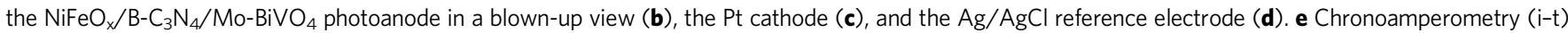
curve of $\mathrm{NiFeO}_{x} / \mathrm{B}_{-} \mathrm{C}_{3} \mathrm{~N}_{4} / \mathrm{Mo}-\mathrm{BiVO}_{4}$ photoanode collected at $0.54 \mathrm{~V}$ vs. $\mathrm{RHE}$ under $\mathrm{AM} 1.5 \mathrm{G}$ illumination in PPB solution $(\mathrm{pH} 7)$. $\mathbf{f} \mathrm{H}_{2}$ and $\mathrm{O}_{2}$ evolution of the

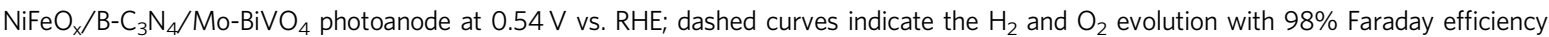

\section{Discussion}

In conclusion, the $\mathrm{NiFeO} / \mathrm{B}-\mathrm{C}_{3} \mathrm{~N}_{4} / \mathrm{Mo}-\mathrm{BiVO}_{4}$ photoanode has provided an archetype to exploit the potential of boosting the photoelectrochemical performance by the synergistic combination of work function tuning and heterojunction construction. The bespoke photoanode achieved a remarkable photocurrent density of $3.85 \mathrm{~mA} \mathrm{~cm}^{-2}$, ABPE of $2.67 \%$ and IPCE of $71 \%$ at $0.54 \mathrm{~V}$ vs. RHE, which are the highest yet reported with the lowest biased-voltage for $\mathrm{BiVO}_{4}$-based PEC materials. The $\mathrm{NiFeO}_{\mathrm{x}} / \mathrm{B}-\mathrm{C}_{3} \mathrm{~N} / \mathrm{Mo}-\mathrm{BiVO}_{4}$ photoanode exhibited significantly enhanced PEC activity for water splitting by systematically work function adjustment (Fig. 6a). We have demonstrated the work function adjustment via Mo doping could reduce the interfacial energy loss and increase the opencircuit photo-voltage of $\mathrm{BiVO}_{4}$ PEC cells. In addition, the creation and optimization of the heterojunction (p-n) of $\mathrm{B}-\mathrm{C}_{3} \mathrm{~N}_{4}$ and Mo$\mathrm{BiVO}_{4}$ with correct charge transfer direction were accomplished by work function adjustment via $\mathrm{B}$ doping for $\mathrm{C}_{3} \mathrm{~N}_{4}$, thereby increasing the separation of photo-generated electron-hole pairs at the $\mathrm{B}-\mathrm{C}_{3} \mathrm{~N}_{4}$ and $\mathrm{Mo}_{-}-\mathrm{BiVO}_{4}$ interface (Fig. 6a, b). The data of DFT calculation, XPS and UPS confirm the Fermi level and band shift of $B-\mathrm{C}_{3} \mathrm{~N}_{4}$ and Mo-BiVO ${ }_{4}$. This synergistic effect between $\mathrm{B}$ doping of $\mathrm{C}_{3} \mathrm{~N}_{4}$ and Mo doping of $\mathrm{BiVO}_{4}$ with the $\mathrm{NiFeO}_{\mathrm{x}}$ OEC has allowed the $\mathrm{NiFeO}_{\mathrm{x}} / \mathrm{B}-\mathrm{C}_{3} \mathrm{~N}_{4} / \mathrm{Mo}-\mathrm{BiVO}_{4}$ photoanode to achieve the record - the highest PEC water splitting performance $(2.67 \% \mathrm{ABPE})$ with a fairly low bias-voltage $(0.54 \mathrm{~V}$ vs. RHE), which shows the efficiency of $\mathrm{ABPE}$ are the highest recorded for $\mathrm{BiVO}_{4}$-based photoanodes $4,7,9,11,13,18,20,43-45$. The demonstration of the $\mathrm{NiFeO}_{\mathrm{x}} /$
B- $\mathrm{C}_{3} \mathrm{~N}_{4} / \mathrm{Mo}-\mathrm{BiVO}_{4}$ photoanode with excellent PEC water splitting capability achieved by the synergistic combination of work function tuning and heterojunction deliberation will inform the design and development of the next-generation PEC materials and devices.

\section{Methods}

Preparation of $\mathbf{B i V O}_{\mathbf{4}}$ and $\mathrm{Mo}_{-} \mathrm{BiVO}_{\mathbf{4}}$ electrode. $\mathrm{BiVO}_{4}$ photoanodes were fabricated by a two-step process via a modified method which was originally developed by Kim and Choi ${ }^{7}$. At first, a template-free electrochemical deposition was applied to prepare the BiOI nanosheets using a conventional three-electrode glass cell, where a piece of F-doped $\mathrm{SnO}_{2}$ coated glass (FTO, Nippon Sheet Glass, $1 \times 2$ $\mathrm{cm}$ ) served as the working electrode, a Pt electrode served as the counter electrode and an $\mathrm{Ag} / \mathrm{AgCl}$ electrode served as the reference electrode. Generally, $50 \mathrm{~mL}$ of solution containing 0.4 M KI (99.0\%, Tianjin Zhiyuan Reagent Co. Ltd.) and 0.04 $\mathrm{M} \mathrm{Bi}\left(\mathrm{NO}_{3}\right)_{3}(99.0 \%$, Shanghai Macklin Biochemical Co. Ltd) was adjusted $\mathrm{pH}$ to 1.7 by adding $\mathrm{HNO}_{3}$ (65-68\%, AR, Guangzhou Chemical Reagent). Then, $20 \mathrm{~mL}$ of absolute ethanol (100\%) containing $0.23 \mathrm{M}$ p-benzoquinone (97\%, Aladdin) was mixed into the above solution and vigorously stirred for several minutes. Cathodic deposition of $\mathrm{BiOI}(1 \times 1 \mathrm{~cm}$ area) was performed potentiostatically in the final solution at $-0.1 \mathrm{~V}$ vs. $\mathrm{Ag} / \mathrm{AgCl}$ at room temperature (RT) for $200 \mathrm{~s}$. The second step was the conversion of $\mathrm{BiOI}$ to $\mathrm{BiVO}_{4}$. Dimethyl sulfoxide (DMSO, AR, Tianjin Damao Reagent) solution containing $0.2 \mathrm{M}$ vanadyl acetylacetonate $\left(\mathrm{VO}(\mathrm{acac})_{2}\right.$, $95 \%$, Aladdin) was impregnated on BiOI electrodes $\left(50 \mu \mathrm{L} \mathrm{cm}^{-1}\right)$ and then annealed in air at $450{ }^{\circ} \mathrm{C}$ for $2 \mathrm{~h}$ with ramping rate of $2{ }^{\circ} \mathrm{C} \mathrm{min}-1$. Lastly, the $\mathrm{BiVO}_{4}$ electrodes were soaked in $1 \mathrm{M} \mathrm{NaOH}$ (AR, Guangzhou Chemical Reagent) solution for $1 \mathrm{~h}$ with gentle stirring to remove the excess $\mathrm{V}_{2} \mathrm{O}_{5}$. The obtained pure $\mathrm{BiVO}_{4}$ electrodes were rinsed by deionizer water and dried at RT.

Molybdenum doped $\mathrm{BiVO}_{4}\left(\mathrm{Mo}-\mathrm{BiVO}_{4}\right)$ photoanodes were prepared in the same way by adding $\mathrm{Na}_{2} \mathrm{MoO}_{4}$ as the Mo source. In detail, 1, 2, and $10 \mu \mathrm{L} 0.1 \mathrm{M}$ $\mathrm{Na}_{2} \mathrm{MoO}_{4}$ (AR, Tianjin Damao Reagent) aqueous solution was added into $1 \mathrm{~mL}$ the above $\mathrm{VO}(\mathrm{acac})_{2}$ DMSO solution before it was impregnated on BiOI electrodes. 
a

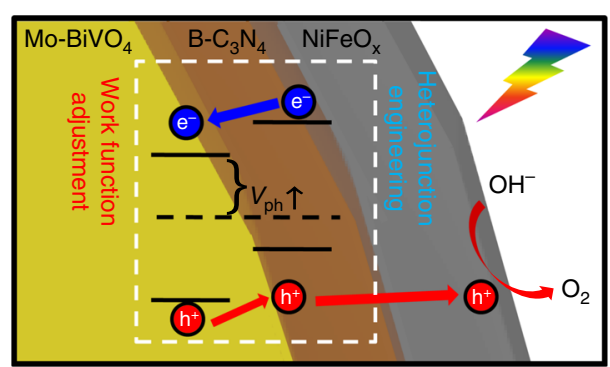

b

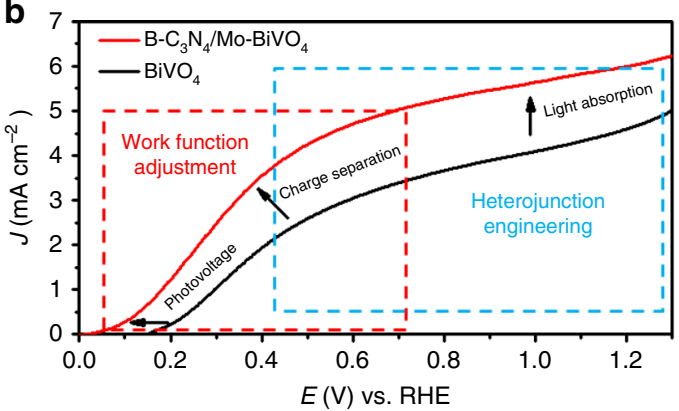

C

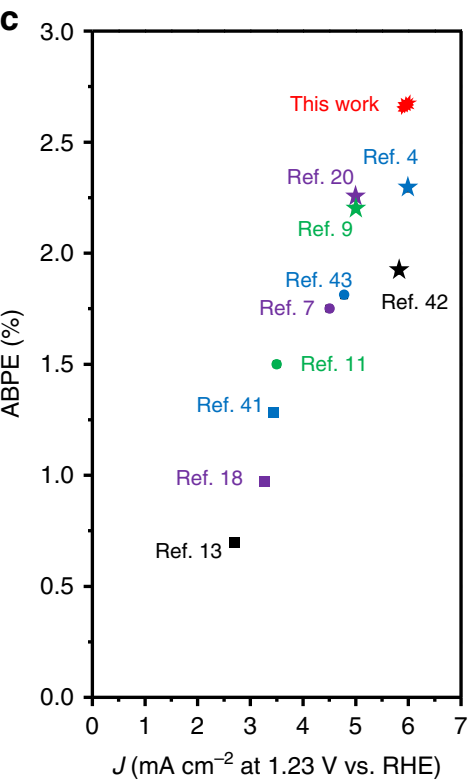

Fig. 6 Photoelectrochemical water splitting characterization. a Schematic diagram illustrating the separation of photo-generated electrons and holes of the

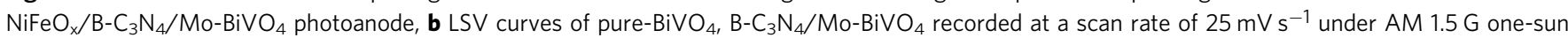
irradiation in PPB solution using $0.5 \mathrm{M} \mathrm{Na}_{2} \mathrm{SO}_{3}$ as a hole scavenger $(\mathrm{pH} 7)$, c specific photocurrent density at $1.23 \mathrm{~V}$ vs. RHE and applied bias photo-tocurrent efficiency (ABPE) of $\mathrm{BiVO}_{4}$ based photoanode $4,7,9,11,13,18,20,41-43$.

The corresponding concentration ratio of $\mathrm{Mo} / \mathrm{Bi}$ was $0.05 \%, 0.1 \%$, and $0.5 \%$, respectively.

Preparation of $\mathbf{C}_{\mathbf{3}} \mathbf{N}_{\mathbf{4}}$ and $\mathbf{B}-\mathbf{C}_{\mathbf{3}} \mathbf{N}_{\mathbf{4}}$. The bulk graphite- $\mathrm{C}_{3} \mathrm{~N}_{4}\left(\mathrm{C}_{3} \mathrm{~N}_{4}\right)$ was fabricated by directly heating low-cost melamine ( $99 \%$, Aladdin). In detail, $5 \mathrm{~g}$ melamine powder was placed in an alumina crucible with a cover, then heated to $500^{\circ} \mathrm{C}$ for $2 \mathrm{~h}$ in a muffle furnace with a heating rate of $2^{\circ} \mathrm{C} \mathrm{min}^{-1}$. The obtained bulk $\mathrm{C}_{3} \mathrm{~N}_{4}$ was grind into small powder, and $100 \mathrm{mg} \mathrm{C}_{3} \mathrm{~N}_{4}$ powder was dispersed in $100 \mathrm{~mL}$ isopropyl alcohol (AR, Tianjin Damao Reagent) and exfoliated by ultrasonication for $24 \mathrm{~h}$ to obtain $\mathrm{C}_{3} \mathrm{~N}_{4}$ nanosheets $\left(\mathrm{C}_{3} \mathrm{~N}_{4}-\mathrm{NS}\right)$. The resultant dispersion was centrifuged at $3000 \mathrm{rpm}$ for $10 \mathrm{~min}$, and the supernatant containing exfoliated $\mathrm{C}_{3} \mathrm{~N}_{4}$-NS was collected by pipette. Boron doped $\mathrm{C}_{3} \mathrm{~N}_{4}$ nanosheets (B- $\mathrm{C}_{3} \mathrm{~N}_{4}-\mathrm{NS}$ ) supernatants were prepared in the same way but heating the mixture of $0.5 \mathrm{~g}$ boric acid (GR, Aladdin) and $5 \mathrm{~g}$ melamine.

Preparation of $\mathbf{C}_{3} \mathbf{N}_{\mathbf{4}} / \mathbf{B i V O}_{\mathbf{4}}$ and $\mathbf{B}-\mathbf{C}_{\mathbf{3}} \mathbf{N}_{\mathbf{4}} / \mathbf{M o}-\mathbf{B i V O}_{\mathbf{4}}$ electrode. The $\mathrm{BiVO}_{4}$ or $\mathrm{Mo}^{-\mathrm{BiVO}_{4}}$ photoanodes were immersed into $20 \mathrm{~mL} \mathrm{C}_{3} \mathrm{~N}_{4}-\mathrm{NS}$ or B- $\mathrm{C}_{3} \mathrm{~N}_{4}-\mathrm{NS}$ supernatants for $1 \mathrm{~h}$. After rinsed with deionizer water, the obtained $\left(\mathrm{B}-\mathrm{C}_{3} \mathrm{~N}_{4} /\right.$ (Mo-) $\mathrm{BiVO}_{4}$ photoanodes were annealed at $350^{\circ} \mathrm{C}$ in air for $1 \mathrm{~h}$ for better combination.

Photoelectrodeposition of $\mathbf{N i F e O}_{\mathbf{x}}$ OEC layer. $\mathrm{NiFeO}_{x}$ OEC layer were synthesized using a simple photoelectrodeposition method reported. $\mathrm{NiFeO}_{\mathrm{x}}$ layer was photoelectrodeposited on the $\mathrm{B}-\mathrm{C}_{3} \mathrm{~N}_{4} / \mathrm{Mo}-\mathrm{BiVO}_{4}$ in $0.4 \mathrm{M} \mathrm{FeSO}_{4}$ and $0.04 \mathrm{M}$ $\mathrm{NiSO}_{4}$ solution at $0.6 \mathrm{~V}$ vs. $\mathrm{Ag} / \mathrm{AgCl}$ (total charge $100 \mathrm{mC} / \mathrm{cm}^{2}$ ) at RT. The $\mathrm{NiFeO}_{\mathrm{x}} / \mathrm{B}-\mathrm{C}_{3} \mathrm{~N}_{4} / \mathrm{Mo}-\mathrm{BiVO}_{4}$ electrode was then washed with deionizer water and dried in air at $60^{\circ} \mathrm{C}$.

Analysis. The as-synthesized products were characterized by a scanning electron microscope (SEM, Zeiss G-500), transmission electron microscopy (TEM, JEOL 2100 F, FEI Tecnai G² F30), X-Ray Diffractometer (XRD, D8 ADVANCE), X-ray Photoelectron Spectroscopy (XPS) and Ultroviolet Photoelectron Spectroscopy (UPS, Thermo Fisher Scientific ESCALab250) and Raman spectroscopy (Renishaw inVia). The optical properties of the products were measured with an UV-vis-NIR Spectrophotometer (UV-vis-NIR, Shimadzu UV-2450).

Photoelectrochemical and electrochemical measurements. All the PEC and electrochemical measurements were carried out in a three-electrode cell with a flat quartz window to facilitate illumination of the photoelectrode surface. The working electrode is the product fabricated in this work, while Pt electrode was used as a counter electrode and $\mathrm{Ag} / \mathrm{AgCl}$ electrode was used as a reference electrode, respectively. The illumination source was AM $1.5 \mathrm{G}$ solar simulator (Newport, LCS 10094011 A (class A, Supplementary Fig. 29) directed at the quartz PEC cell $\left(100 \mathrm{~mW} \mathrm{~cm}^{-2}\right)$. Incident-photon-to-current conversion efficiency (IPCE) were collected by a Solartron 1280B electrochemical station with a solar simulator (Newport 69920, $1000 \mathrm{~W}$ xenon lamp), coupled with an infrared water filter (Oriel 6127) and aligned monochromator (Oriel Cornerstone $1301 / 8 \mathrm{~m}$ ). All the electrochemical measurements were performed on an SP-150 electrochemical workstation (SP-150, Bio-Logic SAS, France) at RT. More PEC and electrochemical calculations are shown in the Supporting information.

\section{Data availability}

The authors declare that the main data supporting the findings of this study are available within the article and its Supplementary Information files. Extra data are available from the corresponding author upon request. All relevant data are available from the authors upon reasonable request.

Received: 21 January 2019 Accepted: 17 July 2019

Published online: 15 August 2019

\section{References}

1. Grätzel, M. Photoelectrochemical cells. Nature 414, 338-344 (1983).

2. Sivula, K. \& Van De Krol, R. Semiconducting materials for photoelectrochemical energy conversion. Nat. Rev. Mater. 1, 15010 (2016).

3. Moniz, S. J. A. et al. Visible-light driven heterojunction photocatalysts for water splitting-a critical review. Energy Environ. Sci. 8, 731-759 (2015).

4. Ye, K.-H. et al. Carbon quantum dots as a visible light sensitizer to significantly increase the solar water splitting performance of bismuth vanadate photoanodes. Energy Environ. Sci. 10, 772-779 (2017).

5. Shi, X. et al. Efficient photoelectrochemical hydrogen production from bismuth vanadate-decorated tungsten trioxide helix nanostructures. Nat. Commun. 5, 4775 (2014).

6. Abdi, F. F. et al. Efficient solar water splitting by enhanced charge separation in a bismuth vanadate-silicon tandem photoelectrode. Nat. Commun. 4, 2195 (2013).

7. Kim, T. W. \& Choi, K.-S. Nanoporous BiVO4 photoanodes with dual-layer oxygen evolution catalysts for solar water splitting. Science 343, 990-994 (2014).

8. Park, Y., McDonald, K. J. \& Choi, K. Progress in bismuth vanadate photoanodes for use in solar water oxidation. Chem. Soc. Rev. 42, 2321-2337 (2013).

9. Kim, T. W. et al. Simultaneous enhancements in photon absorption and charge transport of bismuth vanadate photoanodes for solar water splitting. Nat. Commun. 6, 8769 (2015)

10. Ye, K.-H. et al. A novel $\mathrm{CoOOH} /(\mathrm{Ti}, \mathrm{C})-\mathrm{Fe} 2 \mathrm{O} 3$ nanorod photoanode for photoelectrochemical water splitting. Sci. China Mater. 61, 887-894 (2018). 
11. Zhong, M. et al. Surface modification of CoOx loaded BiVO4 photoanodes with ultrathin p-type $\mathrm{NiO}$ layers for improved solar water oxidation. J. Am. Chem. Soc. 137, 5053-5060 (2015).

12. Zhong, D. K., Choi, S. \& Gamelin, D. R. Near-complete suppression of surface recombination in solar photoelectrolysis by "Co-Pi" catalyst-modified W: BiVO4. J. Am. Chem. Soc. 133, 18370-18377 (2011).

13. Chang, $X$. et al. Enhanced surface reaction kinetics and charge separation of p-n heterojunction Co3O4/BiVO4 photoanodes. J. Am. Chem. Soc. 137, 8356-8359 (2015).

14. Abdi, F. F. et al. The origin of slow carrier transport in BiVO4 thin film photoanodes: a time-resolved microwave conductivity study. J. Phys. Chem. Lett. 4, 2752-2757 (2013).

15. Ding, K. et al. Why the photocatalytic activity of Mo-doped BiVO4 is enhanced: a comprehensive density functional study. Phys. Chem. Chem. Phys. 16, 13465-13476 (2014).

16. Xi, Y. et al. First-principle study on the photocatalystic properties of tungsten doped monoclinic BiVO4 crystallites. Adv. Mater. Res. 873, 845-849 (2014).

17. Nasir, S. N. F. M. et al. New insights into Se/BiVO4 heterostructure for photoelectrochemical water splitting: a combined experimental and DFT study. J. Phys. Chem. C 121, 6218-6228 (2017)

18. Ye, K.-H. et al. BiOI-BiVO4 photoanodes with significantly improved solar water splitting capability: $\mathrm{p}-\mathrm{n}$ junction to expand solar adsorption range and facilitate charge carrier dynamics. Nano Energy 18, 222-231 (2015).

19. Zhang, H., Yu, Y., Zhang, L. \& Dong, S. Fuel-free bio-photoelectrochemical cells based on a water/oxygen circulation system with a Ni: $\mathrm{FeOOH} / \mathrm{BiVO} 4$ photoanode. Angew. Chem. 130, 1563-1567 (2018).

20. Kuang, Y. et al. A front-illuminated nanostructured transparent BiVO4 photoanode for $>2 \%$ efficient water splitting. Adv. Energy Mater. 6, 1501645 (2016).

21. Pilli, S. K. et al. Cobalt-phosphate (Co-Pi) catalyst modified Mo-doped BiVO4 photoelectrodes for solar water oxidation. Energy Environ. Sci. 4, 5028-5034 (2011).

22. Pihosh, Y. et al. Photocatalytic generation of hydrogen by core-shell WO3/BiVO4 nanorods with ultimate water splitting efficiency. Sci. Rep. 5, 11141 (2015).

23. Kosar, S. et al. Highly efficient photocatalytic conversion of solar energy to hydrogen by WO3/BiVO4 core-shell heterojunction nanorods. Appl. Nanosci. 17, 1-8 (2018).

24. Jiang, C. et al. Facile synthesis of g-C3N4/BiVO4 heterojunctions with enhanced visible light photocatalytic performance. Ceram. Int. 43, 301-307 (2017).

25. Safaei, J. et al. Enhanced photoelectrochemical performance of Z-scheme gC3N4/BiVO4 photocatalyst. Appl. Catal. B Environ. 234, 296-310 (2018).

26. Raziq, F. et al. Enhanced cocatalyst-free visible-light activities for photocatalytic fuel production of g-C3N4 by trapping holes and transferring electrons. J. Phys. Chem. C 120, 98-107 (2015).

27. Yan, S. C. et al. Photodegradation of rhodamine B and methyl orange over boron-doped g-C3N4 under visible light irradiation. Langmuir 26, 3894-3901 (2010).

28. Lu, C. et al. Boron doped g-C3N4 with enhanced photocatalytic UO22+ reduction performance. Appl. Surf. Sci. 360, 1016-1022 (2016).

29. $\mathrm{Li}, \mathrm{H}$. et al. A g-C3N4/WO3 photoanode with exceptional ability for photoelectrochemical water splitting. Mater. Chem. Front. 1, 338-342 (2017).

30. Li, C. et al. Monoclinic porous BiVO 4 networks decorated by discrete g-C3N4 nano-islands with tunable coverage for highly efficient photocatalysis. Small 10, 2783-2790 (2014).

31. Sun, Q. et al. Effect of contact interface between $\mathrm{TiO} 2$ and g-C3N4 on the photoreactivity of g-C3N4/TiO2 photocatalyst:(001) vs (101) facets of $\mathrm{TiO} 2$. Appl. Catal. B Environ. 164, 420-427 (2015).

32. Madhusudan, P. et al. Novel urea assisted hydrothermal synthesis of hierarchical $\mathrm{BiVO} 4 / \mathrm{Bi} 2 \mathrm{O} 2 \mathrm{CO} 3$ nanocomposites with enhanced visible-light photocatalytic activity. Appl. Catal. B Environ. 110, 286-295 (2011).

33. Rettie, A. J. E. et al. Combined charge carrier transport and photoelectrochemical characterization of BiVO4 single crystals: intrinsic behavior of a complex metal oxide. J. Am. Chem. Soc. 135, 11389-11396 (2013).

34. Zhang, L. et al. Plasmonic enhancement in BiVO4 photonic crystals for efficient water splitting. Small 10, 3970-3978 (2014).

35. Nair, V. et al. Textured nanoporous Mo: BiVO4 photoanodes with high charge transport and charge transfer quantum efficiencies for oxygen evolution. Energy Environ. Sci. 9, 1412-1429 (2016).

36. Xie, S. et al. NiO decorated Mo: BiVO4 photoanode with enhanced visiblelight photoelectrochemical activity. Int. J. Hydrog. Energy 39, 4820-4827 (2014).
37. Antony, R. P. et al. Electrospun Mo-BiVO4 for efficient photoelectrochemical water oxidation: direct evidence of improved hole diffusion length and charge separation. Electrochim. Acta 221, 173-182 (2016).

38. Vaidyanathan, S. et al. Catalysis with TiO2/gold nanocomposites. Effect of metal particle size on the Fermi level equilibration. J. Am. Chem. Soc. 126 4943-4950 (2004).

39. Wood, A. et al. Fermi level equilibration in quantum dot-metal nanojunctions. J. Phys. Chem. B 105, 8810-8815 (2001).

40. Tan, H. L. et al. BiVO $4\{010\}$ and $\{110\}$ relative exposure extent: governing factor of surface charge population and photocatalytic activity. J. Phys. Chem Lett. 7, 1400-1405 (2016).

41. Yin, W. J. et al. Doping properties of monoclinic BiVO4 studied by firstprinciples density-functional theory. Phys. Rev. B 83, 970-978 (2011).

42. Kawaguchi, M. et al. Syntheses and structures of new graphite-like materials of composition BCN(H) and BC3N(H). Chem. Mater. 8, 1197-1201 (1996).

43. Fujimoto, I. et al. WO3/BiVO4 composite photoelectrode prepared by improved auto-combustion method for highly efficient water splitting. Int. J. Hydrog. Energ. 39, 2454-2461 (2014).

44. Qiu, Y. et al. Efficient solar-driven water splitting by nanocone BiVO4perovskite tandem cells. Sci. Adv. 2, e1501764 (2016).

45. Yu, F. et al. Fabrication and kinetic study of ferrihydrite modified BiVO4 photoanode. ACS Catal. 7, 1868-1874 (2017).

\section{Acknowledgements}

The authors acknowledge the financial support from the National Science Fund for Distinguished Young Scholars (21425627), Natural Science Foundation of ChinaSINOPEC Joint fund (U1663220), Local Innovative and Research Teams Project of Guangdong Pearl River Talents Program (2017BT01C102), Shenzhen Peacock Plan (KQTD2016053015544057) and Nanshan Pilot Plan (LHTD20170001), NSFC/Hong Kong RGC Research Scheme (N_HKUST610/14), Fund for Innovative Chemical Experiment and Research of School of Chemistry and Chemical Engineering, Sun Yatsen University. We thank He Lin for helpful discussion.

\section{Author contributions}

H.J. and S.Y. supervised this project; K.Y., H.L. and D.H. designed and conducted the experiments; S.X., W.Q. and W.M. calculated the DFT results; W.Q. and M.L. performed the PEC oxidations; K.Y. and H.L. wrote the manuscript.

\section{Additional information}

Supplementary Information accompanies this paper at https://doi.org/10.1038/s41467019-11586-y.

Competing interests: The authors declare no competing interests.

Reprints and permission information is available online at http://npg.nature.com/ reprintsandpermissions/

Peer review information: Nature Communications would like to thank Yuriy Pihosh, X. Y.Wang, and other, anonymous, reviewers for their contributions to the peer review of this work.

Publisher's note: Springer Nature remains neutral with regard to jurisdictional claims in published maps and institutional affiliations.

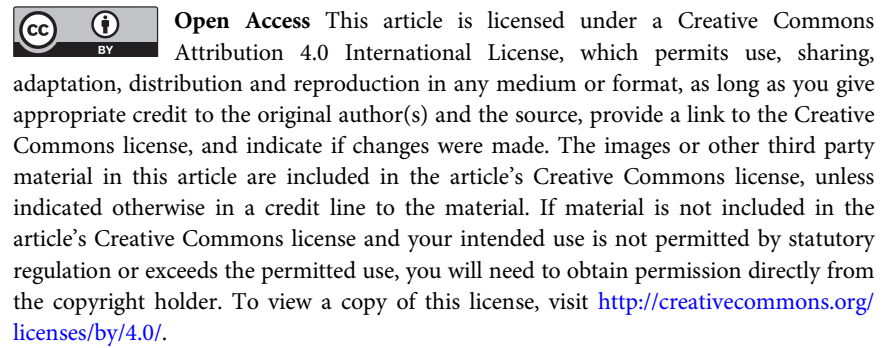

(C) The Author(s) 2019 